\title{
Biodiversity Impact of Green Roofs and Constructed Wetlands as Progressive Eco-Technologies in Urban Areas
}

\author{
Sonja Knapp ${ }^{1,2} \mathbb{D}$, Sebastian Schmauck ${ }^{3}$ and Andreas Zehnsdorf ${ }^{4, *}$ \\ 1 Current address: Helmholtz Centre for Environmental Research—UFZ, Department Community Ecology, \\ Theodor-Lieser-Str. 4, 06120 Halle (Saale), Germany; sonja.knapp@ufz.de \\ 2 Department of Ecology, Technische Universität Berlin, Rothenburgstr. 12, 12165 Berlin, Germany \\ 3 Federal Agency for Nature Conservation, Karl-Liebknecht-Str. 143, 04277 Leipzig, Germany; \\ sebastian.schmauck@bfn.de \\ 4 Helmholtz Centre for Environmental Research-UFZ, Centre for Environmental Biotechnology, \\ Permoserstraße 15, 04318 Leipzig, Germany \\ * Correspondence: andreas.zehnsdorf@ufz.de
}

Received: 3 September 2019; Accepted: 15 October 2019; Published: 21 October 2019

\begin{abstract}
The total amount of sealed surfaces is increasing in many urban areas, which presents a challenge for sewerage systems and wastewater treatment plants when extreme rainfall events occur. One promising solution approach is the application of decentralized eco-technologies for water management such as green roofs and constructed wetlands, which also have the potential to improve urban biodiversity. We review the effects of these two eco-technologies on species richness, abundance and other facets of biodiversity (e.g., functional diversity). We find that while green roofs support fewer species than ground-level habitats and thus are not a substitute for the latter, the increase in green roof structural diversity supports species richness. Species abundance benefits from improved roof conditions (e.g., increased substrate depth). Few studies have investigated the functional diversity of green roofs so far, but the typical traits of green roof species have been identified. The biodiversity of animals in constructed wetlands can be improved by applying animal-aided design rather than by solely considering engineering requirements. For example, flat and barrier-free shore areas, diverse vegetation, and heterogeneous surroundings increase the attractiveness of constructed wetlands for a range of animals. We suggest that by combining and making increasing use of these two eco-technologies in urban areas, biodiversity will benefit.
\end{abstract}

Keywords: biological diversity; climate adaptation; ecosystem services; green roofs; multifunctionality; resilience; stormwater management; urban development; urban green infrastructure; urban nature conservation

\section{Introduction}

Increasing urban population numbers [1] around the world necessitates higher building densities in order to preserve agricultural and (semi-)natural land. However, inner-urban green spaces help to preserve biodiversity and improve human well-being $[2,3]$.

Urban green infrastructure (UGI) is a network of (semi-)natural and designed green spaces and elements in cities. It can offer high quality habitats for biodiversity and deliver a range of ecosystem services [4]. Elements of this green network include parks, street trees, urban forests, cemeteries, community gardens, green roofs and façades, wetlands, and riverbanks, for example.

Urban green infrastructure plays an important role in current policy strategies such as the EU biodiversity strategy to 2020 [5], the European Commission's paper on Green Infrastructure (GI) - 
Enhancing Europe's Natural Capital [6] and the TEEB studies on "The Economics of Ecosystems and Biodiversity (TEEB)" [7]. In a similar manner, in Germany, the protection of UGI against construction activities and the improvement of green spaces in terms of habitat quality are closely linked to the "30-hectare target", which aims at sealing no more than that amount per day up to 2020 according to Germany's National Sustainability Strategy [8]. "Dual inner development" [9] is the key strategy to meet this target. The strategy's core is that on the one hand, "[ ... ] revitalization of derelict industrial, military and transport facilities, in-fill development or densification are implemented to reduce the high consumption of undeveloped land [ ... ]" [9] (p. 246), while on the other hand, inner-urban open spaces must be developed, linked with each other and qualitatively improved. This way, the strategy aims at reducing the pressures of increasing urban population numbers on UGI, its biodiversity and ecosystem services.

"Dual inner development" coincides with urban dwellers' preference for biodiverse over low-diversity green spaces. A pattern that has been demonstrated across a range of European cities, regardless of people's socio-cultural or migrant backgrounds [10]. In Germany, people acknowledge that UGI represents urban nature [11]. Parks, other public green spaces and even brownfields [11] are regarded as worth protecting [12]. The promotion of UGI is thus of utmost importance for biodiversity conservation and has high approval among urban dwellers.

With rising temperatures and more frequent heavy rain events in the context of climate change for Germany, see: [13], the relevance of UGI for shading and evapotranspiration and the infiltration capacity of unsealed surfaces is increasing. Especially in urban areas with their high degree of sealing, heavy rain $\left(\geq 15 \mathrm{l} / \mathrm{m}^{2}\right.$ in $1 \mathrm{~h}$, https://www.dwd.de/DE/service/lexikon/Functions/glossar.html?lv2=102248\&lv3= 102572) can easily swamp drainage systems $[14,15]$. Therefore, the treatment and evapo(transpi)ration of rainwater and, in certain cases, of greywater too at the locations where they arise are becoming increasingly important [16].

One very promising approach in this regard is the decentralization of urban water management by using biodiversity-promoting eco-technologies such as green roofs and constructed wetlands [17]. Green roofs do not occupy ground-level surfaces, they can regulate a building's climate [18], reduce the urban heat island effect [19], improve urban air quality [20], add to rainwater retention [21], remove contaminants from rainwater [22], and provide habitat for flora and fauna [23,24]. Constructed wetlands have been optimized for the treatment of domestic wastewater. Their simple design, low energy requirements, and low implementation costs make them ideal components of decentralized water management systems [25]. In addition, they can be used to treat locally arising rainwater and/or greywater [26]. Wetland plants as basic components of constructed wetlands have a high rate of evapotranspiration, thus transferring a significant amount of water to the surrounding air [27]. The amount of wastewater entering sewer systems can thus be reduced by $60-75 \%$ [28], at the same time reducing water treatment costs. Moreover, this eco-technology provides environmental conditions that have become scarce in urban landscapes, where many water bodies and natural wetlands have been lost [29,30], together with their biodiversity [31].

In this paper, we summarize and discuss the effects of green roofs and constructed wetlands on biodiversity in urban areas, based on findings from a systematic literature review. We also derive recommendations for the biodiversity-friendly design of these two eco-technologies.

\section{Materials and Methods}

On August 9, 2018, we conducted a systematic literature review [32] by searching all databases within the ISI Web of Science (WoS) for TOPIC = " green roof" AND diversity AND (arthropod* OR bats* OR birds* OR fungi* OR lichen* OR moss* OR plant*)) and TOPIC = ("constructed wetland" AND diversity AND (amphibian* OR arthropod* OR bats* OR birds* OR fungi* OR lichen* OR moss* OR plant* OR reptile*)). Our search covered all years from 1945 until the date of search. Search terms were designed to cover articles dealing with the diversity of species groups likely to occur within or to use sites of one of the two eco-technologies. In addition, we considered articles not included in WoS 
that had been published in one of three special issues on green roofs and their biodiversity that we found using Google Scholar (Urban Habitats 4, December 2006, http://www.urbanhabitats.org/v04n01, Urban Ecosystems 11, 2008, https://link.springer.com/journal/11252/11/4/page/1, Urban Naturalist SI 1, 2018, https://www.eaglehill.us/URNAonline/urna-sp1-2018.shtml). We did not include books or grey literature in order to focus on peer-reviewed international studies.

In the second step, we scanned the abstracts of all articles, retaining those that seemed to focus on (i) one of the two eco-technologies (for green roofs not only including roofs intentionally greened but also those spontaneously colonized by plants and animals-cf. [33]) and (ii) effects of that technology on biodiversity but excluding others (Figure 1). We then extracted the following details from the selected full text articles:

- Whether a study had been conducted in an urban area

- The country and city in which a study had taken place

- The type of roof (green/brown/conventional roof, intensive/extensive, experimental) or of constructed wetland (laboratory scale vs. full scale)

- The number of roofs studied

- The length of the study period

- The focal species group(s)

- Whether cultivated and/or spontaneously occurring species were in focus

- Species richness and abundance reported in a study

- Trends in species richness and abundance

- Other reported diversity measures and their trends, such as functional diversity indices, numbers of rare and endangered or native and exotic species

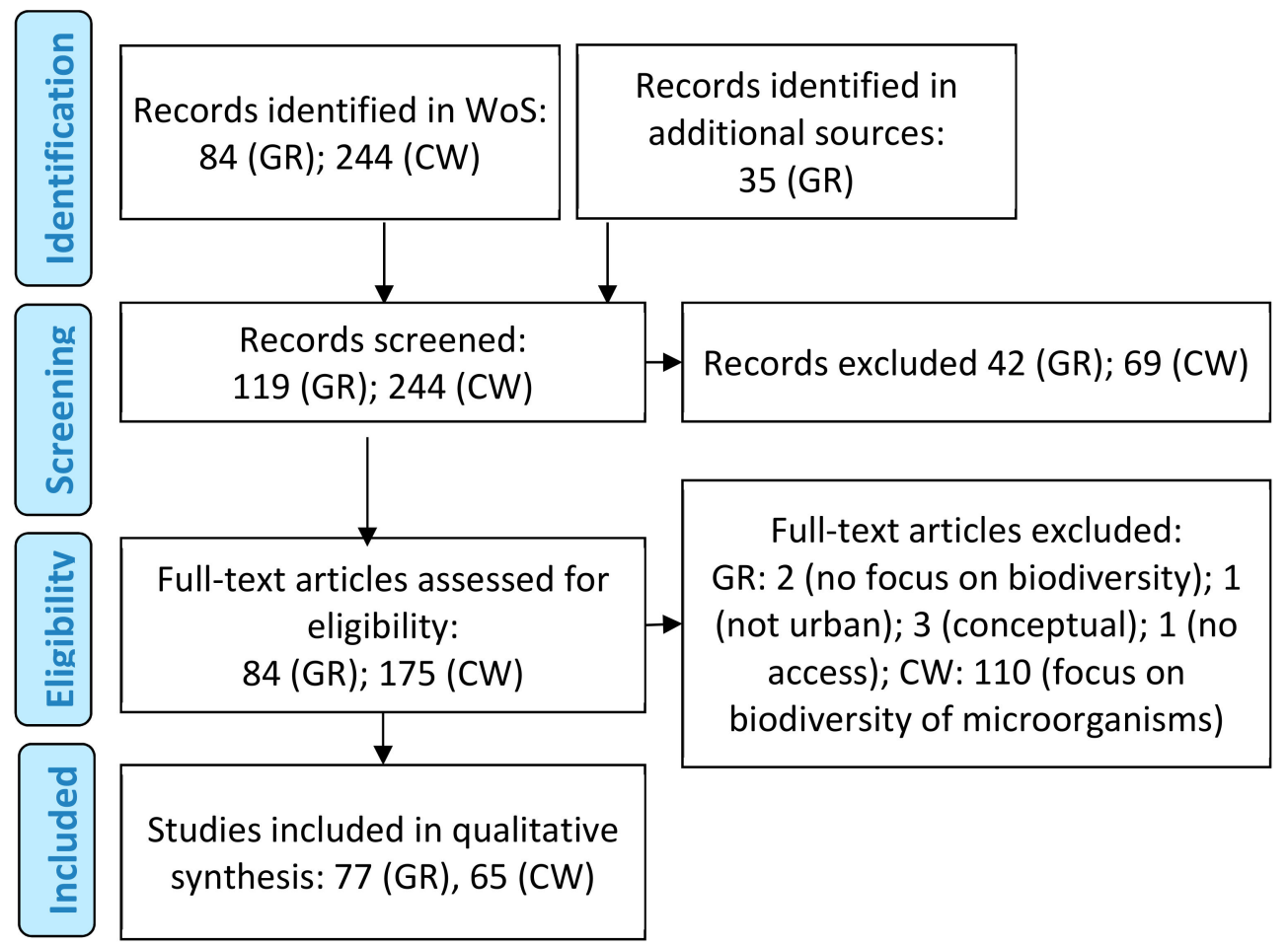

Figure 1. PRISMA Flow Diagram [34] illustrating the approach of selecting scientific articles that investigated the biodiversity impacts of either green roofs (GR) or constructed wetlands (CW) in urban areas. WoS $=$ Web of Science, additional sources $=$ Urban Habitats 4, December 2006, http: //www.urbanhabitats.org/v04n01/, Urban Ecosystems 11, 2008, https://link.springer.com/journal/11252/ 11/4/page/1, Urban Naturalist SI 1, 2018, https://www.eaglehill.us/URNAonline/urna-sp1-2018.shtml. 
Articles were excluded if it turned out that they did not fulfil criteria (i) and/or (ii) defined above, if a study had not been conducted in an urban area, if an article was conceptual, if we could not obtain access to the article (online or through a direct request to the author), or (for constructed wetlands), if the focus was on microorganisms (Figure 1). In the following section, we summarize results both quantitatively and qualitatively as suggested by Pickering and Byrne [32].

\section{Results and Discussion}

Our search (Figure 1) yielded 119 articles on green roofs (84 from WoS, 35 from additional sources, Table S1), and 244 articles on constructed wetlands (all from WoS, Table S2). Of these, we included 84 green roof articles and 175 constructed wetland articles in further analysis.

\subsection{Green Roofs}

\subsubsection{Patterns in Green Roof Research}

Of the 84 green roof articles identified as eligible (Figure 1; Table S1), we had full-text access to 83. Of these, we excluded six because they were conceptual, did not focus on urban areas or did not test the effects of green roofs on biodiversity. Sixty-one $(79.22 \%)$ of the remaining 77 articles exclusively focused on urban areas, $16(20.78 \%)$ on both urban and rural areas. Most studies had taken place in the UK (15 of 77 articles/19.48\%), US (13/16.88\%), Canada (12/15.58\%), Germany (9/12\%), Switzerland (8/11.69\%), France (4/5.19\%), and Austria (2/2.60\%). Some studies covered several of these countries. One study each came from Belgium, China, Israel, Italy, Japan, and Turkey. Thirteen articles (16.88\%) did not focus on a specific country but were instead review or opinion pieces. The cities most often considered were London (UK) and Halifax (Canada) with 10 articles (13.33\%) each, Zurich (Switzerland) with five articles (6.66\%), Berlin (Germany), Chicago and New York (US) with four articles (5.33\%) each, and other cities with fewer articles. This shows that, while studies on green roof biodiversity are spread across Asia, Europe, and North America, especially Southern Hemisphere regions and cities have not been investigated in this respect, yet (or not published within the international peer-reviewed literature) - a pattern common across urban biodiversity research [35]. Broadening the geographic focus of green roof biodiversity studies will help in identifying both general and specific patterns and will broaden our knowledge of species able to inhabit green roofs, as these might differ for example, among temperate and tropical regions.

Seventy-one articles $(92.21 \%)$ investigated green roofs, others focused on brown roofs ( 3 articles, $3.90 \%$ ), concrete or gravel roofs ( 1 article/1.30\% each). Of the 71 articles investigating green roofs, 20 $(25.97 \%)$ included experimental roofs (i.e., roofs divided into modules and equipped with different treatments such as different substrate depths and types, temperature, moisture, mowing regime or plant combinations), 23 (29.87\%) included extensive (non-experimental) roofs, nine (11.69\%) included intensive (non-experimental) roofs, and all other articles were not specific.

Twenty-four of all 77 articles (31.17\%) reported results from one roof, three studies (3.90\%) included $>100$ roofs, the rest considered between two and 57 roofs. The study period was less than a year in 22 studies $(28.57 \%)$, varied between 1 and 10 years in 29 studies $(37.66 \%)$, was greater than 10 years in six studies $(7.80 \%)$, and not reported in 20 studies (25.97\%).

With regard to species groups, $41(53.25 \%)$ of the 77 articles analyzed vascular plants, $25(32.47 \%)$ arthropods, six $(7.80 \%)$ bryophytes, five $(6.49 \%)$ birds, two $(2.60 \%)$ each bats, fungi and lichen, and one $(1.30 \%)$ each mollusks and microbes (with some studies covering several of these groups). Seven articles $(9.10 \%)$ were not specific. Thirteen $(16.88 \%)$ of the 77 articles focused on cultivated species, 35 focused on spontaneous/wild species (45.45\%), 28 (36.36\%) on both, and one (1.30\%) was not specific. Accordingly, although a range of taxonomic groups has been investigated, research is strongly biased towards vascular plants and arthropods. Such taxonomic bias is common across ecological research [36-38]. As not every species can colonize roofs, it is to be expected that some (e.g., flightless) taxa will be missing or be less common. Again, by broadening our geographic focus of green roof biodiversity, taxonomic bias might be reduced as well. 


\subsubsection{Trends in Green Roof Species Richness}

Fourty (51.95\%) of the 77 articles reported species numbers but with different focuses: Some reported total numbers across roofs or across groups of species, others reported average numbers per roof, per group of species or per treatment. Comparative/experimental studies included tests of ground level sites vs. green roofs, extensive vs. intensive roofs, green roofs vs. conventional roofs (the latter classified here as roofs covered by e.g., concrete or gravel, that are not intentionally greened and not managed), as well as effects of roof age, height, area, connectivity, substrate depth, irrigation, shading, and mowing, addition of mycorrhizal fungi, structural diversity, plant diversity, and plant cover on the richness of the focal species group (Table 1 ).

Table 1. Summary of the response of biodiversity (species richness, species abundance, functional diversity) to roof characteristics based on 77 articles on roof biodiversity.

\begin{tabular}{cccc}
\hline Roof Characteristics & Species Richness & Species Abundance & Functional Diversity \\
\hline Age & $\rightarrow(8)$ & $\rightarrow(13)$ & N.A. \\
Area & $\uparrow(1)$ & $\uparrow(1)$ & N.A. \\
Connectivity & $\nearrow(2)$ & $\nearrow(3)$ & $\nearrow(1)$ \\
Conventional a & $\searrow(5)$ & $\downarrow(2)$ & N.A. \\
Extensive b $_{\text {Height }}$ & $\searrow(5)$ & N.A. & N.A. \\
Irrigation & $\nearrow(3)$ & $\downarrow(3)$ & N.A. \\
Mowing & $\uparrow(1)$ & $\uparrow(1)$ & N.A. \\
Mycorrhiza & $\rightarrow(1)$ & N.A. \\
Plant cover & $\uparrow(1)$ & $\rightarrow(3)$ & N.A. \\
Plant diversity & $\uparrow(2)$ & $\uparrow(1)$ & $-(1)$ \\
Roof compared to ground & $\uparrow(2)$ & $\searrow(7)$ & $-(1)$ \\
Shade & $\searrow(7)$ & $\uparrow(2)$ & N.A. \\
Substrate depth & $\uparrow(3)$ & $\uparrow(2)$ & N.A. \\
Structural/habitat diversity/heterogeneity & $\uparrow(5)$ & $\nearrow(7)$ & $-(1)$ \\
\hline
\end{tabular}

$\uparrow=$ All studies show increase in biodiversity parameter, $\nearrow=$ Majority of studies shows increase in biodiversity parameter, $\rightarrow=$ Mixed evidence, $\searrow=$ Majority of studies shows decrease in biodiversity parameter, $\downarrow=$ All studies show decrease in biodiversity parameter, - = No study found an effect, yet, N.A. = no study documenting the effect was found. Numbers in brackets indicate the number of studies reporting the trend. a: "Conventional" shows biodiversity patterns on conventional roofs as compared to green roofs, with e.g., $\downarrow$ depicting lower biodiversity values on conventional than green roofs. b: "Extensive" shows biodiversity patterns on extensively vs intensively managed roofs, with e.g., \ depicting a majority of studies showing lower biodiversity values on extensive than intensive roofs.

Roof age had varying effects on species richness: Short-term studies usually reported decreasing richness after the start of an experiment, e.g., for micro-arthropods in a nine-month study in London, UK [39] or for vascular plants over three years in Haifa, Israel [40]. Vascular plant richness first increased, then levelled off or decreased within six months on an experimental green roof in London [41]. With regard to long term-studies, spontaneous vascular plant richness increased with roof age in a chronosequence of conventional roofs in Knox County, Tennessee, US [42]. However, no trend for vascular plant richness was found in a 1 to 93 years chronosequence of roofs in Berlin and Neubrandenburg, Germany [43]. A 30-year study in Hanover, Germany, where roofs were left to natural succession after initial sowing [44], reported an increase in the total richness ( $\gamma$-diversity) of vascular plant species, a decrease in richness per plot ( $\alpha$-diversity), and an increase across plots ( $\beta$-diversity). Richness in succulent plants decreased, while richness in grasses and herbs increased on a green roof in Norman, Oklahoma [45]. No difference in collembolan richness was reported for young vs. old roofs in Hanover [46].

Speciess richness tends to be higher at ground-level sites than roofs for fungi [47], birds [48], bees [49], and other arthropods/invertebrates [44,45] but see [46]. The overall tendency of lower roof richness corresponds to roof height decreasing spider richness in France [50] and vascular plant richness in Knox County [42]. However, height had no effect according to a review on the horizontal and vertical 
island biogeography of arthropods on green roofs-but this review again showed a tendency towards higher ground-level richness [51]. The fact that green roofs support fewer species than ground-level habitats stresses that they should not be used as a substitute for other green spaces and thus not as an "excuse" for sealing ground-level habitat. Green roofs will never be able to host more than those species adapted to roof environmental conditions [24] such as vertical and horizontal isolation or limited substrate depth [23]. It is, however, to be expected that the more green roofs exist in a city, the better connectivity among all components of UGI will become. The positive effects of site connectivity or of an increasing proportion of ground-level habitat in the areas around roofs were shown for the richness of spiders, weevils, and bees but for carabids with a hump-shaped relationship, [43,45]. Mobile species that are able to fly, able to disperse by wind, or that are transported by other species, and that at the same time tolerate the harsh conditions of green roofs [52], will benefit from increasing green roof numbers. Similarly, roof area should support species richness. However, Madre et al. [50] were the only researchers to explicitly test for the effects of roof area, showing a positive effect on hymenopteran richness, as would be expected from the species-area relationship.

The effects of harsh roof conditions (especially heat and aridity) are reflected in lower numbers of arthropod species on extensive than intensive green roofs [53,54]. Nonetheless, extensive roofs hosted more bird species than semi-extensive roofs [55] and brown/biodiverse roofs supported more invertebrate species than green roofs [56]. Conventional roofs, which can be seen as being the harshest of all roofs, supported fewer species of birds and arthropods than green roofs $[55,57]$ but equal richness of bats [58,59] and birds [59] foraging on roofs. Overall, it can be expected that conventional roofs are less rich in plants and animals [23] but highly mobile taxa, such as bats and birds, might show no preferences in their use of roofs if these provide food or nesting resources. On the other hand, bat activity increased over roofs characterized by high plant diversity [60].

Substrate depth is closely linked to the green roof type, with intensive roofs usually carrying deeper substrates than extensive roofs. Deep substrates support a richness of vascular plants and arthropods [61-64], as they dehydrate more slowly than shallow substrates [65]. Exceptions to this pattern exist $[66,67]$, for example with effects of substrate depth on plant species richness varying across time [68]. For overwintering insects, the substrate should at least be $15 \mathrm{~cm}$ in depth in order to ensure animal survival during frost periods. Earth bumblebees and ants, for example, require even deeper substrates to build their nesting colonies. The conditions of shallow substrates, while being harsh for target species, have the potential to reduce the invasion of non-target species as shown by Nagase et al. [69] (but see Dunnett et al. [64], who reported higher diversity of colonizing plant species with shallow substrates). Overall, roof conditions are comparatively harsh and are thus selective for stress-tolerant species [52], but deep substrates, irrigation [70] and also shade or the addition of mycorrhizal fungi [68] improve roof conditions.

Shade can be fostered by an increase in plant cover, which increased the richness of true bugs in 115 green roofs across France [501, and the richness of C3-, C4-grasses, and forbs on 10 green roofs in New York [71]. Recently, solar panels, which can be installed on green roofs (Figure 2), were suggested as ways to create shady sites, with the change of shaded and non-shaded roof areas increasing habitat heterogeneity [72,73].

Generally, an increase in roof habitat heterogeneity should support species richness, at least by reducing species mortality [63]. To increase heterogeneity, Walker and Lundholm [634 suggest adding logs and pebble piles, Grant [74] and Madre et al. [50] suggest increasing vegetation structural diversity. While mowing can support plants flowering in spring or summer [75], mowing some but not other roof areas will increase heterogeneity, too. Plant diversity itself introduces heterogeneity, thus supporting the richness of other taxa, such as weevils and spiders [66]. 


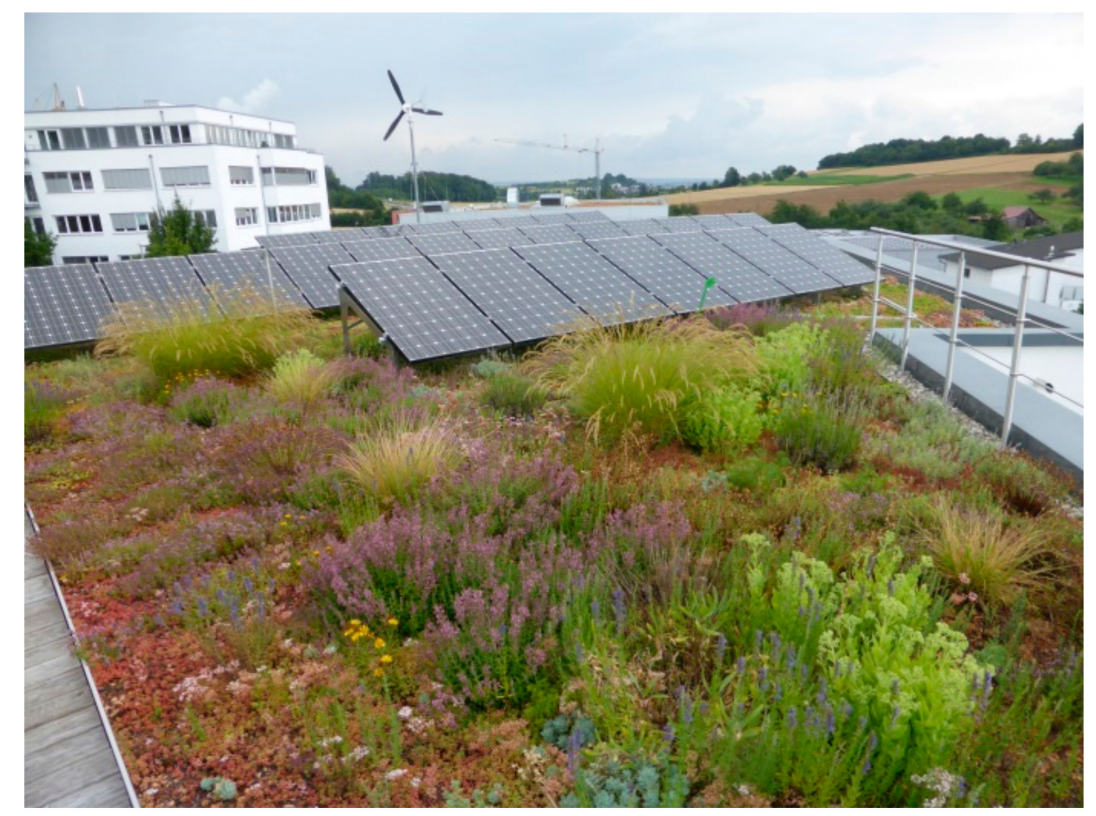

Figure 2. Combinations of vegetation and solar panels on green roofs, such as on this roof by ZinCo, Germany, can increase habitat heterogeneity. (Photo: A. Z.).

\subsubsection{Trends in Green Roof Species Abundance}

Twenty-two (28.57\%) of the 77 articles reported details on species abundance. Some of them showed that thousands of specimens exist on green roofs, especially arthropods [46,76,77]. Abundance on green roofs can even exceed abundance at ground level $[47,56,78]$ but is usually lower $[49,79,80]$, decreasing with roof height $[42,51,60]$. Functional traits play an important role in determining which species can bridge the distance between the ground and roofs, with, for example, the abundance of large insects that spend most of their adult lives flying not differing in abundance between roofs and the ground [79].

In comparison to conventional roofs, Williams et al. [23] suggest that green roofs should support a greater abundance of species. Indeed, bird and arthropod abundance was higher on the green than conventional roofs in New York [57]. A natural green roof, with structurally rich equipment in the form of deadwood, mocks, stones, different substrates, water surfaces, nesting, and shelter facilities, serves to increase and to preserve biodiversity [81]. The abundance of insects on a green roof is a good proxy for the adoption of the roof as habitat and for the abundance of birds (e.g., breeding, food resources). In Switzerland, Baumann [82] investigated the breeding success of little ringed plovers (Charadrius dubius) and northern lapwings (Vannellus vannellus) on five greened flat roofs over a period of two years. The results showed that while northern lapwings started to breed, they were not successful in the long term, as the chicks died after a few days [82]. In the following years, chicks survived, probably because the abundance of invertebrates, and thus the birds' food resource, increased [83].

As for ground-level habitats, green roof species abundance has been shown to depend on the regional species pool, environmental conditions, adaptation to these conditions (and thus functional traits), and species interactions. With regard to species interactions, it seems that neighboring species mainly have facilitative effects on green roof plant biomass [84]. Nonetheless, plant species abundance can vary in response to the life forms present in a species community [85]. Species can also benefit from a lack of neighboring species, and thus reduced competition [69]. With regard to environmental conditions, the effects of substrate depth, shade, irrigation, and habitat heterogeneity on plant abundance have been reported for green roofs. Again, functional traits play a role, with succulent Sedum and also moss species thriving in shallow substrates but other (mainly non-succulent but also Sedum species [86]) species (e.g., grasses) gaining in dominance with increasing substrate depth [61,64]. Consequently, overall plant abundance increases with substrate depth $[62,63,70,87]$ as it does with irrigation [71] 
and shade [88,89], i.e., favorable conditions. Increased vegetation cover and height, in turn, affect arthropods, with species such as bees that mainly prefer open, sunny sites decreasing in abundance but species such as many spiders that hunt within vegetation increasing in abundance [73]. Mowing and the associated reduction in plant height decreased the dominance of plant species flowering in spring or summer [75] — which in turn fostered other species. Structural diversity of green roofs, in general, seems to increase arthropod abundance [50], with different habitats and different plant species supporting varying arthropod abundances [39,72].

With regard to temporal trends in plant abundance, these essentially resemble successional patterns known from ground-level habitats, with annual therophytes often dominating initial stages but declining afterwards, perennial species increasing [90-92], and shrubs or meadows developing in the long-term, depending on environmental constraints such as moisture [92]. Also, with increasing roof age, plant species spontaneously colonize roofs [42,45] and overall plant abundance tends to increase $([43,89,93,94]$ but see $[41,69])$. A few studies have investigated temporal trends in animal abundance, showing no difference in collembolan abundance among young and old roofs in Hanover, Germany [46] and a decrease in microarthropod abundance after initial planting of roof plots on a green roof in London, UK [39]. Studies on the effects of roof size on abundance were scarce, too, with only Madre et al. [50] showing a positive response of arthropods.

Effects of habitat connectivity on species abundance have hardly been investigated so far, and results vary: The higher the amount of suitable ground level habitat present in the surroundings of a green roof, the higher bat activity over the roof was $[58,60]$. However, surrounding habitat did not affect bee abundance [49], again indicating that the functional traits of species, such as their foraging distance, affect their use of roof habitats.

\subsubsection{Trends in Green Roof Functional Diversity and Patterns in Functional Traits}

Twenty-nine (37.66\%) of the 77 articles provided information on trait patterns or measures of functional diversity. The latter, such as functional richness, dissimilarity, divergence, and evenness, Rao's Q [95] and community-weighted mean [96] have been calculated in four studies only.

In these studies, the functional richness of springtails (Collembola) was higher on intensive than extensive roofs in Paris [53], and higher in roof habitats dominated by herbaceous vs. Sedum species across Europe [62]. Therefore, more favorable roof conditions seem to support a larger range of trait values than harsh conditions.

No differences were shown for measures indicating trait dissimilarity in a community, such as Rao's Q of arthropods in ground-level habitats vs. green roofs, or with increasing substrate depth in Zurich [66], and functional dissimilarity and divergence of springtails in intensive vs. extensive green roofs [53]. The lack of such differences might point towards strong environmental filters shaping all these habitats, which is in line with studies showing that community assembly in urban habitats usually is dominated by filtering processes [97]. However, Rao's $Q$ increased with connectivity for bees and was U-shaped for weevils, increased with plant richness for spiders but responded in a hump-shaped manner to the proportion of bare ground [66]. High connectivity will increase the range of species that can enter green roofs and thus, a higher diversity of trait values should be present (although Holt [98] stated that the chance that species from less disturbed habitats become established is low), high plant richness increases niche diversity and thus helps functionally different species to establish on green roofs.

Functional evenness, which indicates whether trait values in a community are uniformly distributed or not, was similar for springtails on intensive vs. extensive green roofs [ 53 but higher for vascular plants on roofs dominated by Sedum vs. herbaceous species [62].

The community-weighted mean (CWM), which is the abundance-weighted mean of a trait's distribution in a species community, can be used to identify shifts in mean trait values with changing environmental conditions [99]. It is therefore not surprising that springtails' CWM differed between intensive and extensive roofs, with intensive roofs supporting a lower abundance of species with 
spherical body shape but more species reproducing sexually, and without ocelli or furcular, but no differences for body length and pigmentation [53]. On 15 green roofs left to natural succession in Hanover, Germany, within 30 years, the CWM of vascular plants indicated a shift from species dispersing by wind and competitors to species dispersing by animals, and species adapted to warm-dry and ruderal conditions such as therophytes [44].

Other trait patterns (mainly: percentage of species with certain trait values in a green roof community) were reported by 26 articles (11 on vascular plants, two on birds, and 13 on arthropods).

For plants, wind-dispersed and mechanically dispersed species tend to be more frequent than animal-dispersed species [42,69,100], although McKinney and Sisco [42] could not show a relation between roof height and the main dispersal mode of spontaneous species. Pollination and reproduction were investigated in one study only, but this study [100] showed for 115 green roofs across France that roughly half of all spontaneous plant species were insect-pollinated, thus indicating that a range of insects visit green roofs. Reproduction was most common by seeds [100]. Long- and short-lived species were evenly distributed [54,69,72]. Among life form types, hemicryptophytes were most abundant on spontaneously colonized roofs [87,92], and dominance of life forms on extensive green roofs varied with climate [89]. Although, a preference for using succulents exists within cultivated species [101] and roofs mainly promote stress-tolerant traits (e.g., evergreen habit, succulence, CAM-photosynthesis, [102]), Lundholm et al. [94] were able to show a high variation in leaf traits and plant height on a green roof in Halifax.

For birds, urban avoider species were more frequent on the green than conventional roofs in New York [57]. Moreover, extensive roofs hosted birds feeding on more food types than intensive roofs [55], showing the benefit green roofs can provide within densely built landscapes.

For bees, green roofs support both social and solitary species, ground- or cavity-nesting, polylectic species [49,66,103], and species of varying body size (more small and medium sized bees in Chicago [80], but less small than medium or large bees in Toronto, [104]). Generalists (e.g., polyphagous) species were common among other arthropods as well [50], as were highly mobile $[50,105])$ and thermo- or xero-thermophilic species $[50,76]$. Harsh roof conditions were also reflected in the high number of stenotopic grassland species and pioneer vegetation on green roofs across Switzerland [105].

\subsubsection{Patterns of Rare and Endangered Species on Green Roofs}

Nine (11.69\%) of the 77 articles reported on the rarity or endangerment (e.g., Red List status) of species. In one of these studies, only common or generalist species were recorded (arthropods on a green roof in Chiba City, Japan [54]). All other studies emphasized the occurrence of rare or endangered species such as spiders [56], beetles [67,105,106], arthropods in general [73], and vascular plants $[100,107]$. However, this result might be biased, as neither the presence nor the absence of rare or endangered species might always be mentioned. Nonetheless, the low number of studies reporting rarity or endangerment is in line with Williams et al. [23], who stated that the conservation value of green roofs is poorly documented so far and that green roofs mainly support generalists.

\subsubsection{Patterns of Native vs. Exotic Species on Green Roofs}

Ten $(12.99 \%)$ of the 77 articles reported whether species were native or exotic. Seven of these investigated vascular plant species and partly reported high percentages of exotic species: $61.5 \%$ on spontaneously colonized roofs across Knoxville and Knox County, USA [42], 50\% on a green roof in Chiba City [54], 47.06\% across 37 green roofs in Trabzon City, Turkey [87], and 70\% of all cultivated plant species across 115 green roofs in France [100]. However, green roofs do not generally seem to be hotspots of exotic plant species: On a green roof in Rotherham, UK all weeds were native species from dry-open land [69], and in France, 85.8\% of spontaneous plant species were native [100]. However, these studies lasted for only 0.75 and 0.16 years, respectively, and exotic species might become established in the long-term. Kinlock et al. [101] emphasized that succulent species from 
Eurasia, especially Sedum species, have been planted on green roofs across the world, thus fostering biotic homogenization.

Five of the ten articles reported results on native vs. exotic arthropod species, and these found lower percentages of exotics than studies on plants: On a green roof in Toronto, 12 of 17 bee species were native and there was no difference in the abundance of native vs. exotic bee species [104]. Moreover, less than $10 \%$ of arthropods were exotic in Chiba City [54]. Nonetheless, geographic differences exist, with beetle species being all native in Europe but mostly exotic in North America (as shown by Starry et al. [106] for 41 green roofs for five cities in Switzerland, Germany, Canada, and the US). Moreover, compared to ground-level habitats, green roofs had a higher proportion of exotic bee species in Chicago [49].

\subsection{Constructed Wetlands}

\subsubsection{Patterns in Constructed Wetland Research}

Of the 244 articles on constructed wetlands found in WoS, we selected 175 for a further assessment of impacts on biodiversity. Articles that we excluded dealt with very specific topics related to plant-microorganism interactions or technical applications, without direct reference to biodiversityfor example:

- Effects of root characteristics of wetland plants on nutrient decomposition [108]

- Viruses in wetland ecosystems, with the result that little is known about this topic [109]

- Native herbaceous plant species with potential use in phytoremediation of heavy metals with a focus on wetlands [110]

- Borrow pits (ponds created during highway construction) — not wetlands for water treatment purposes [111]

- Mitigation wetlands that are created for nature conservation, not wastewater treatment (e.g., [112-114])

- Wastewater reuse for fiber crop cultivation as a strategy to mitigate desertification [115]

- Assessment of pathogenic bacteria in treated greywater and irrigated soils [116]

- Impact of trout aquaculture on water quality and farm effluent treatment options [117]

Most of the 175 studies were conducted in China (71 articles/40.57\%) and the US (29/16.57\%), followed by Spain $(9 / 5.14 \%)$, Canada $(8 / 4.57 \%)$ and Portugal (7/4.00\%). In Ireland and Tunisia, four studies each (2.29\%) were compiled, in Estonia, Italy, Singapore and Sweden there were three studies $(1.71 \%)$, with two studies (1.14\%) each in Australia, Brazil, Denmark, France, Germany, Israel, Ivory Coast, and Oman. One study each came from Austria, Belgium, Ethiopia, Hungary, India, Japan, Korea, Pakistan, Poland, the Netherlands, and the United Kingdom. Thus, the geographic scope of these studies is broader than for studies on green roof biodiversity, reflecting the broad interest in green, decentralized technologies for wastewater removal. Four articles $(2.29 \%)$ did not focus on a particular country, instead they were reviews. Sixty-three studies (36\%) were realized on a laboratory scale and $108(61.71 \%)$ on a full scale. The majority of studies $(104 / 59.43 \%)$ directly related to urban areas.

In contrast to our analysis of green roof biodiversity, 33 of the articles on constructed wetlands $(18.86 \%)$ do not specify a focal species group. Instead, biodiversity is discussed more broadly-for example: "Wetlands are among the world's most productive environments and are cradles of bio-logical diversity, providing the water and primary productivity upon which countless species of plants and animals depend for survival" [118] (357). Microorganisms (bacteria, archaea) represent by far the largest group of investigated organisms (96 articles, $54.86 \%$ ). Here, a special focus is on the interaction of microorganisms with plants that are the basis of water purification in constructed wetlands. Only $13(7.43 \%)$ of the 175 publications mainly deal with plants. The high proportion of studies on microorganisms results from the importance of this group for the treatment performance of constructed wetlands. All other organisms play a subordinate role. Still, these other organisms can use constructed wetlands as foraging and/or nesting habitat, such as in urban areas where natural wetlands are rare. 
Of the examined publications, six (3.43\%) presented results on amphibians, five (2.86\%) on arthropods, four $(2.29 \%)$ on birds, two each $(1.14 \%)$ on invertebrates, ciliates, and fungi, and one only $(0.57 \%)$ on mammals. However, the article on mammals concluded "[ ... ] that a wetland constructed for the treatment of mine water drainage can provide secondary benefits as habitat for a variety of mammal species" [119] (154). Thus, there might be a mismatch between mammals inhabiting constructed wetlands and interest in these mammals. Also, transitory species that use constructed wetlands for foraging during migration but not for nesting, might often not be detected.

\subsubsection{Impacts of Constructed Wetlands on Biodiversity}

Constructed wetlands (Figure 3) have been successfully applied in a range of countries, especially in the decentralized sector for the treatment of different types of polluted wastewater (municipal or industrial wastewater, contaminated river water). Their success has mainly been assessed in terms of water purification performance. Moreover, constructed wetlands can contribute to maintaining or improving biodiversity, especially in urban areas [120]. However, this aspect has received little attention so far. Assessments of the biodiversity of constructed wetlands have mainly been performed in comparison to natural wetlands or, less frequently, to other constructed wetlands [121]. In urban areas, however, constructed wetlands usually do not replace natural wetlands, instead, they are located on previously disused sites or on sites renatured after the demolition of buildings. To our knowledge, comparative studies of the biodiversity of constructed wetlands vs. disused or renatured urban sites do not exist yet.

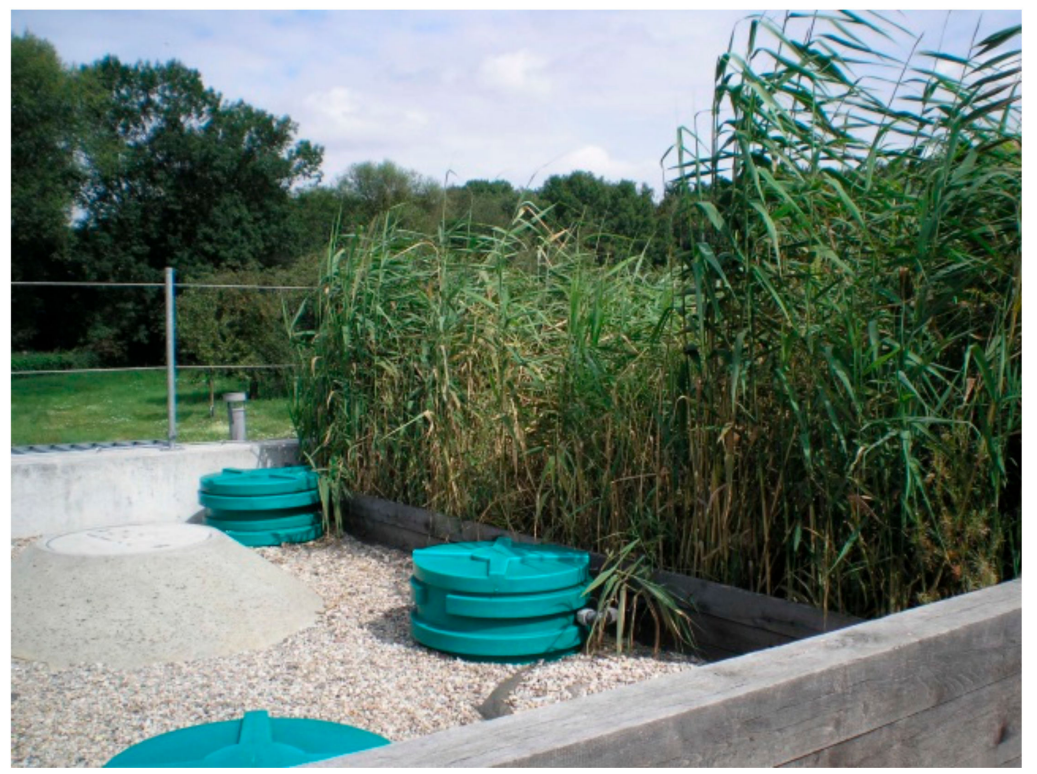

Figure 3. Constructed wetlands usually consist of planted basins where water purification takes place and technical elements such as those seen in the foreground of this photo (Photo: P. Mosig).

As a detailed analysis of the biodiversity of microorganisms would be beyond the scope of this publication, we do not consider this group in further detail. Consequently, the number of articles in focus decreases to 65 (Table S2). Of these 65 publications, 18 investigate animals. The one article dealing with mammals [119] showed that their diversity was higher in constructed wetlands than in wetlands based on traditional reclamation methods. However, mammals are mobile and use both constructed and natural wetlands primarily as a source of food and water or for hiding if plant cover is dense. If a mammal species is present in large numbers, this can also cause problems in wetlands, as the example of the muskrat (Ondatra zibethicus) shows. In the Netherlands, the muskrat is considered a pest and a year-round control program is in force [122]. Kadlec et al. [123] describe the transformation of a constructed wetland with dense vegetation to a patchwork of open and emergent areas caused 
by a high density of muskrats ( $>20$ animals per hectare). "At such an exacerbated scale, muskrat herbivory may be termed as an 'eatout' [...]" [123] (143). Greenhorn et al. [124], on the other hand, point out that the low number of muskrats in the Lake Ontario study area is worrying, as muskrats are generally recognized as "ecosystem engineers" and their loss has the potential to affect wetlands both biotically and abiotically. It has to be noted here that muskrats are native in North America but non-native in Europe.

Birds are another group of highly mobile animals. Natural wetlands can lose their attractiveness for breeding birds through natural processes, such as being overgrown with vegetation over time. If constructed wetlands are regularly maintained, they can act as habitat for breeding water birds in the long term. The progressive loss of natural wetlands around the world increases the importance of constructed wetlands for this group of birds [125]. For example, during an annual bird count, 84 bird species with a total of 7776 individuals were recorded at a large wastewater treatment plant in southwestern Poland [125]. In a 25-year study, Scarton [126] showed that over time, water bird communities increase in species numbers and mean yearly abundance. Lin et al. [127] identified an increase in the evenness and richness of both birds and amphibians at a constructed wetland in Taiwan. In Sweden, constructed wetlands have been successfully applied to reduce the transport of nitrogen from agricultural catchment areas to the Swedish coast. These constructed wetlands have significant impacts on the species richness of water birds and amphibians, they even have positive effects on the occurrence of Red List species [128].

Urbanization is regarded as one of the main reasons for the decrease of amphibians worldwide [129], but local amphibian populations can be supported by the creation of constructed wetlands. The attractiveness of such wetlands for amphibians can be improved by supporting the growth of submerged plants and by shaping the surroundings in an amphibian-friendly manner [129]. For example, Drayer and Richter [130] reported that many species observed in natural wetlands occur less frequently in shallow constructed wetlands and not at all in deep constructed wetlands. Most constructed wetlands do not have a drying cycle, and therefore specifically support predator species (e.g., Lithobates catesbeianus, L. clamitans, and Notophthalmus viridescens) that do not require such cycles. However, Furman et al. [131] showed that constructed wetlands can help to preserve the gene flow between subpopulations of $L$. sylvaticus in urbanized environments. Regardless of the value of wetlands' surroundings for the terrestrial phase of amphibians' life cycle, hardly any study has been carried out on this topic so far. Mulkeen et al. [132] compared terrestrial habitats in the surroundings of natural vs. constructed wetlands with regard to the demands of Lissotriton vulgaris and concluded that by removing barriers, constructed wetlands could become significantly more attractive to this species of newt. Shulse et al. [133] analyzed the amphibian populations of 49 constructed wetlands in northern Missouri. They found that these wetlands should be fish-free and dense in vegetation in order to provide effective protection for amphibians. Moreover, constructed wetlands should include shallow zones of water (Figure 4) and be located in areas characterized by low levels of anthropogenic disturbance [133].

Another group of animals relevant to wetlands is arthropods, particularly insects. Early studies on the impacts of constructed wetlands on native invertebrate populations mainly focused on mosquitoes. Walton and Workman [134] found that the occurrence of Culex-mosquitoes in constructed wetlands depends on the planted vegetation and on the presence of open water. In 2012, Walton [135] (173) made the following observation for constructed wetlands including open water: "Design features, maintenance activities and the characteristics of the wastewater undergoing treatment contribute differentially to potential levels of mosquito production and, consequently, to threats to human and animal health from mosquito-borne pathogens". The management of constructed wetlands and, in particular, vegetation and the presence of fish also have major effects on the diversity of water beetles [136,137]. The colonization of constructed wetlands by shore flies (Diptera: Ephydridae) depends on the growth and maturity of aquatic vegetation. Steinly [138] observed the maximum diversity of higher Diptera in the transition zone between constructed wetlands and terrestrial 
surroundings. Integrated constructed wetlands for the treatment of agricultural wastewater in Ireland that consist of a number of connected ponds serve as habitat for a range of organisms, including macroinvertebrates [139]: A total of 134 taxa have been recorded, the most frequent of which were Coleoptera (66 taxa, 49\%), Hemiptera (20 taxa, 15\%), Diptera (11 taxa, 8\%), Gastropoda (11 taxa, 8\%), Trichoptera (9 taxa, 7\%), and Hirudinea (5 taxa, 4\%). Clean ponds (i.e., those last in line) supported a particularly high diversity of macroinvertebrates [139]. Therefore, Becerra-Jurado [140] suggested that the number of ponds should be increased to a minimum of five and that the expanse of water should be increased as well. Holtmann et al. [141] showed that rainwater ponds in urban areas play an important role in the preservation of dragonflies and for endangered species in particular. Regular maintenance and thus high habitat quality of these ponds compensated for the low quality of the surrounding urban landscape (Figure 5).

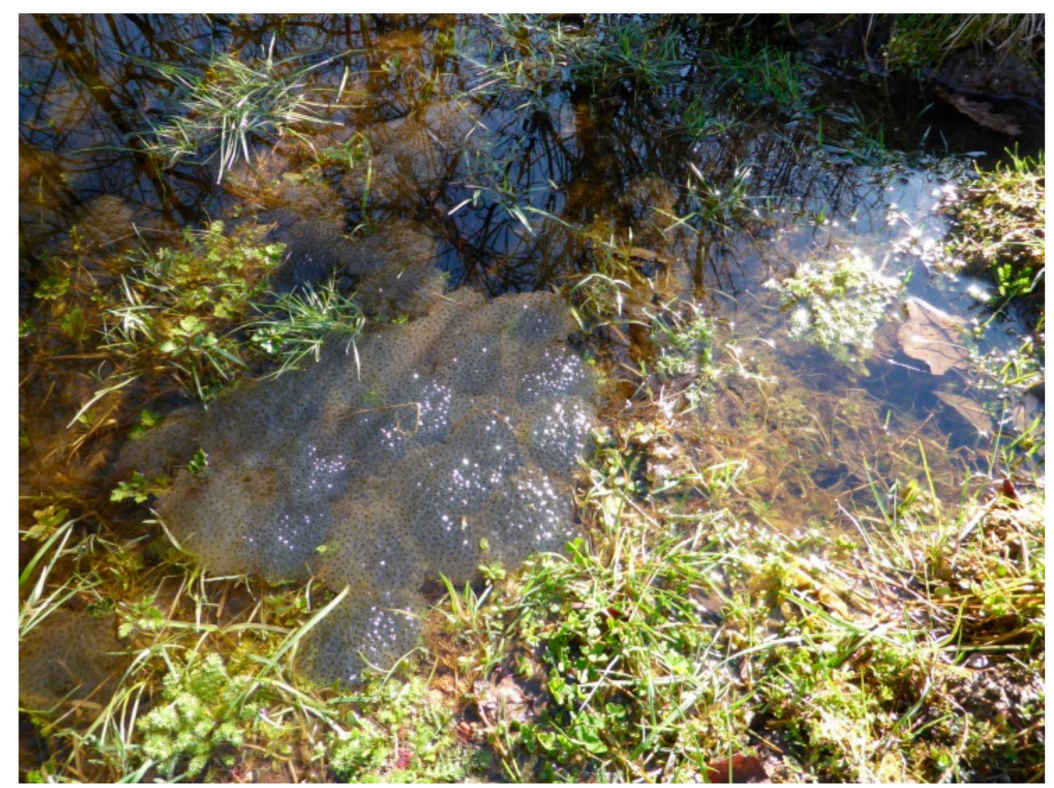

Figure 4. Shallow zones of water within constructed wetlands support spawning amphibians (Photo: A. Z.).

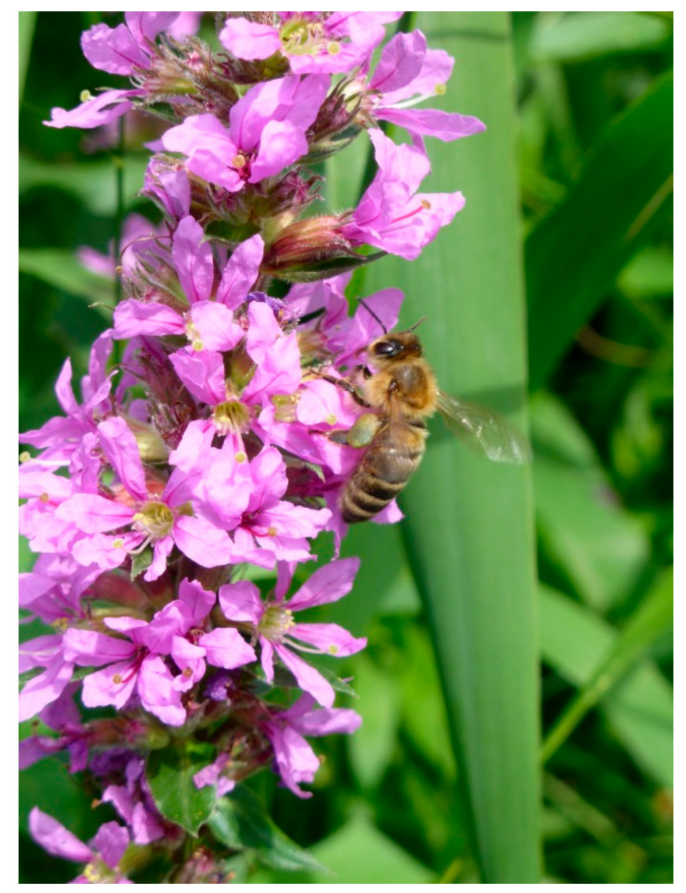

Figure 5. Marsh plants such as Lythrum salicaria provide food resources for insects (Photo: A. Z.). 
Giordano et al. [142] investigated the influence of vegetation cover and aeration regime on the diversity and abundance of nematodes and springtails (Collembola) in a constructed wetland. Nematodes were most frequent in non-planted and non-aerated areas, while springtails were most numerous in planted and non-aerated areas. Based on this, the authors hypothesized that vegetation offers various niches for bacteria and fungi and provides protection against predators and bad weather. A comparative study of macroinvertebrates in the sediment of constructed wetlands planted with Panicum maximum and unplanted control basins showed that most macroinvertebrates (11 subclasses: Oligochaeta, Hymenoptera, Coleoptera, Diptera, Dermaptera, Lepidoptera, Hemiptera, Isopoda, Araneae, Diplopoda, Gasteropoda) occurred in the upper layer (depth of 0 to $10 \mathrm{~cm}$ ) of the planted basin. Diversity reduced significantly with increasing depth: Representatives of seven subclasses were found between 10 and $20 \mathrm{~cm}$, and just two subclasses were identified between 20 and $30 \mathrm{~cm}$. The corresponding depth segments of unplanted control basins supported only half as many subclasses [143]. Moreover, the density of vegetation can affect the structure of macrofauna in constructed wetlands [144], for example by positively affecting the occurrence of Metazoa [145]. Conversely, Spieles and Horn [146] showed that macroinvertebrates are not well suited as indicators of succession in constructed wetlands as they are primarily affected by the availability of nutrients. Plants in constructed wetlands can also promote the development of aphids. For example, Zehnsdorf et al. [147] observed an increase in the occurrence of aphids-probably the mealy plum aphid (Hyalopterus pruni)—in a constructed wetland planted by reed on a pilot scale in Germany (Figure 6). This species of aphid seeks out reed as a summer host, while it spends winter on stone fruit trees such as plum or peach trees [148]. This could promote its occurrence in urban areas. However, these insects also have a range of adversaries in the form of predators and parasites [149].

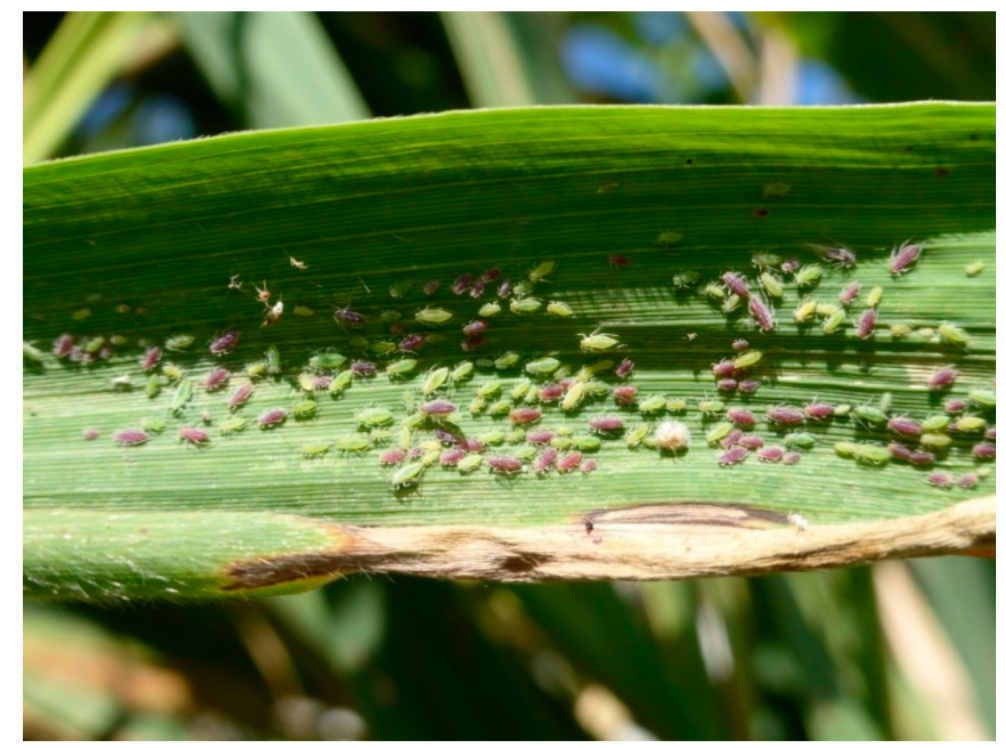

Figure 6. Aphids feeding on Phragmites australis in a constructed wetland (Photo: A. Z.).

\section{Conclusions}

\subsection{Opportunities to Increase the Biodiversity of Green Roofs}

Green roofs can foster biodiversity, deliver a range of ecosystem services $[18,19,21]$ and thus serve as multifunctional surfaces. Our review shows that different characteristics of green roofs have the potential to increase the diversity of plants and animals. Consequently, it is desirable to design green roofs in ways that promote both biodiversity and ecosystem services. For example, as more frequent heavy rain events are to be expected in the context of climate change [13], the drainage of rainwater by green roofs is of increasing interest. Nowadays, technical solutions exist to increase storage volumes on green roofs and delay the outflow of rainfall water (so-called "retention green 
roofs"). These system solutions include large plastic pressure elements that store water and release it again in a delayed manner. With intensive roof greening, individual storage tiles and plates can store up to $250 \mathrm{l} / \mathrm{m}^{2}$. The average system solution for a green roof has a storage volume-depending on substrate depth-of more than $30 \mathrm{l} / \mathrm{m}^{2}$, which can easily cope with heavy rain. Some systems can also reduce runoff. The possibility of adjusting retention serves to relieve the pre-flooder and outlet channel [150]. Water retention by extensive green roofs can cover $50 \%$ to $60 \%$ of a property's average rainfall for the year. With intensely greened roofs and with considerably thicker substrate depth, this rises to $90 \%$ [151]. At the same time, deep substrates improve roof environmental conditions, resulting in an increase in species richness and abundance and thus in a synergy between biodiversity and rainwater management. As habitat diversity is known to positively affect species diversity across urban and rural landscapes [152], it makes sense not to design all green roofs in a city the same way but rather to install a range of green roof types, both extensive and intensive.

Retention potential also depends on the type of roof greening. Studies show that in this respect, the grass is preferable to Sedum and moss [153]. The diversification of plant species cultivated on roofs-beyond Sedum - will counteract the tendency of worldwide biotic homogenization [101], increase within-roof structural diversity, and consequently promote species richness and abundance. The inclusion of additional structural elements, such as logs and pebble piles, the application of a differentiated mowing regime or the installation of solar panels on top of green roofs [72,73] further supports structural diversity [63], with the latter also creating multifunctionality.

The layout of structured green roofs is essential in fostering biodiversity, even on extensive green roofs, as studies by Brenneisen [154], Catalano et al. [155], Dunnett [156] and Germany's Federal Agency for Nature Conservation have also shown [81] (Figure 7). In this regard, it is necessary to keep in mind that the biodiversity of green roofs can comprise a range of plant and animal species. Therefore, it is important to create shelters and hiding places for spiders, beetles, and isopods as well as nesting holes for other insects. Hiding places can consist of old woods and dead branches. The combination of different nest boxes for insects can be a good solution, to begin with. For winter time, it is essential that the soil substrate is thick enough ( $\geq 15 \mathrm{~cm}$ see [81]), as thin soil will completely freeze during frost periods and consequently kill animals overwintering in soil [157]. This would result in an insect-free roof in spring and thus a lack of feeding resources for young birds nesting on the roof. For birds on green roofs, too, it is important to install nesting boxes for ground-nesters, building-nesters, and for bats [81].

Plants used on green roofs can have a significant impact on green roof biodiversity and the diversity in the area around the roof as well. The use of special seeding material, labeled as "bees meadow" or "butterfly meadow" or "biodiversity mix" in the trade, will foster biodiversity as well-as seeds do not promote the spread of non-native species but instead originate from regional sources [158]. Many municipalities, NGOs and other bodies in Germany for example, sell or distribute seed mixtures to house owners. The aim is to prevent the planting of invasive plants and alien species and to avoid mono-cultures of plants, e.g., sedum-clusters, and their gathering on one roof only.

The combination of green roofs with systems on the ground-such as constructed wetlands-can improve storm water management in an ecological and economically viable manner. Ideally, green roofs should be complemented by common systems for decentralized rainwater management such as hollows, trenches, seeping coverings or cisterns. In Germany, many municipalities offer reduced fees up to 50 percent for homeowners who reduce rainwater runoff on their property [81]. In combination with a reduction of soil sealing, e.g., by grass pavers, green roofs offer enormous potential to provide relief for urban water management. At the same time, such an increase in the amount of urban green infrastructure will increase the connectivity among its elements, with benefits for species richness, abundance, and functional diversity. 


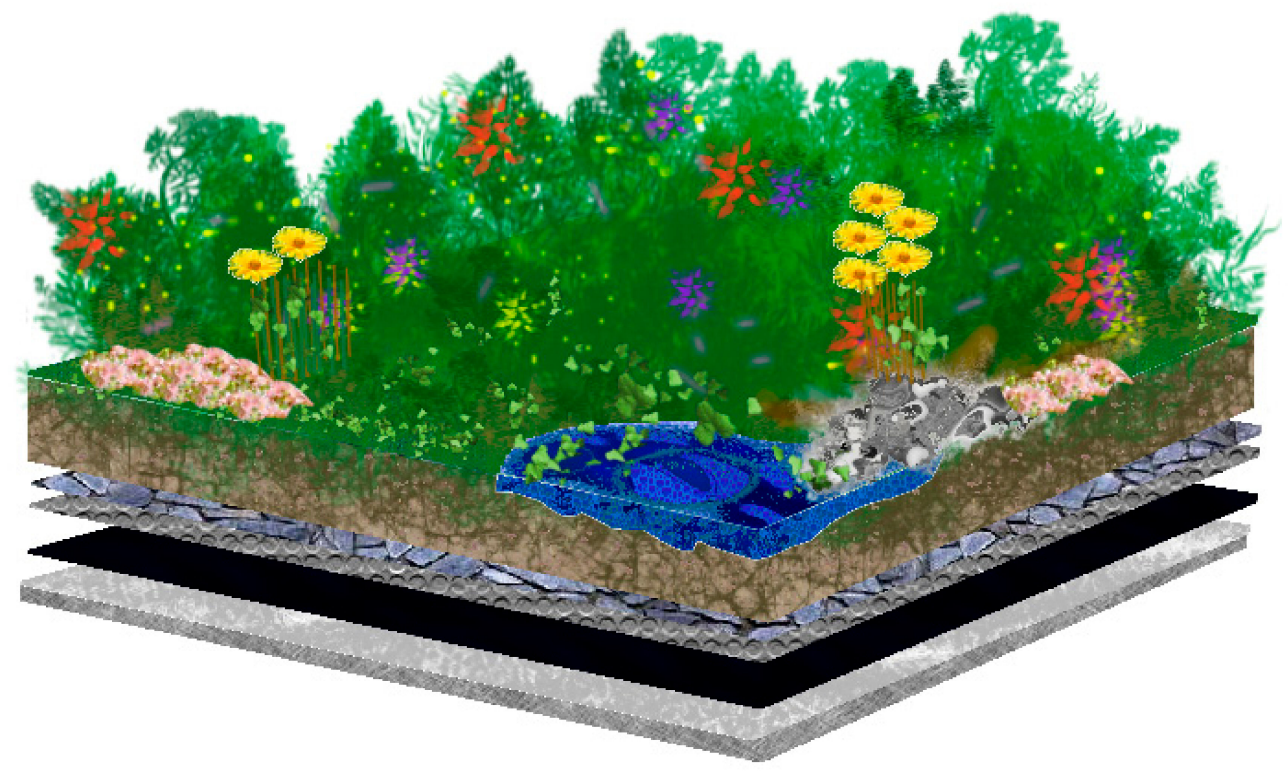

Figure 7. Scheme showing the possible appearance of a biodiverse green roof, based on recommendations by Germany's Federal Agency for Nature Conservation [81]: A structurally diverse roof with vegetation, substrate, gravel, stones, dead wood, and puddles will provide a range of niches that can be occupied by a range of species. The basic layers that make up a green roof are shown as well with (from bottom to top) the roof itself, gravel as drainage system and substrate. (Picture: S. S.).

\subsection{Opportunities to Increase Biodiversity in Constructed Wetlands}

Design and management that is adapted for the living requirements of animals [121] can improve the animal biodiversity of constructed wetlands (Figure 8) used to treat (waste) water. Tailored design of this kind (cf. animal-aided design [159]) and management should include:

- Flat shores

- Barrier-free design of shores

- Vegetation consisting of shore plants and submerged plants

- Varied layout of the wetland's surroundings, including hiding places

- Temporal drying-out of some parts of a wetland

- Minimal disturbance by human activities

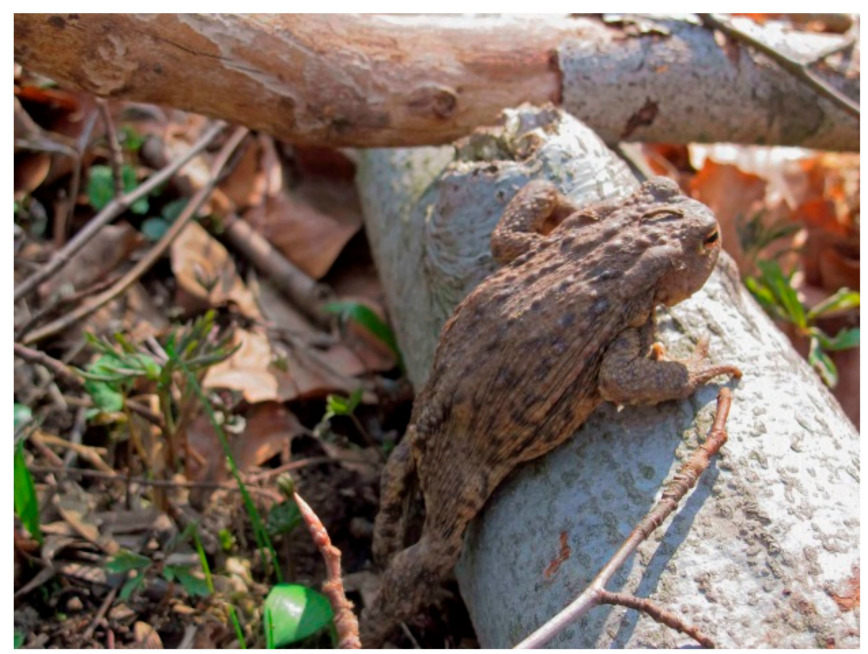

Figure 8. Amphibians can pass natural structures in the surroundings of constructed wetlands much better than surfaces made of concrete or plastic sheets. (Photo: A. Z.). 
As described above, plants—both helophytes and submerged plants—have a major influence on the biodiversity of constructed wetlands. Water quality and, in particular, water contamination are factors that influence the diversity and development of vegetation [160,161]. However, plants can also support the decomposition of certain pollutants [162]. A focus of constructed wetland research is the influence of plants on microorganisms and, specifically, on their performance in the decomposition of substances contained in water [163-167]. In the arrival and establishment phase of wetland succession, the plant diversity of constructed wetlands can exceed that of established natural wetlands $[120,168,169]$. A comprehensive study of vascular plants in a constructed wetland in Grady County, Georgia in the United States showed that their diversity had increased by a factor of 24 over a 9-year period since it was set up. The authors of that study suggested that wild animals (water birds, reptiles and amphibians) supported plant dispersal [170]. Pier et al. [171] showed that plant richness, evenness and diversity were low in a newly created constructed wetland after 12 months of natural succession. Over the period of use of constructed wetlands, a reduction in the diversity of plants can also occur [172], particularly as succession progresses and in the case of targeted planting of very dominant plant species such as Phragmites australis $[173,174]$. Constructed wetlands that are rich in plant species and not dominated by monocultures are generally more effective not just with regard to water purification, particularly the removal of nutrients and pollutants, but they can also sequester carbon, thus adding to climate adaptation and mitigation [175].

It is essential that other issues are taken into account when optimizing and planning constructed wetlands besides the capacity of constructed wetlands to improve water quality. For example, shallow water depth and large surface area combined with a structurally diverse shore can promote high biodiversity of birds, benthic invertebrates and macrophytes, even if this may be associated with a fall-off in purification efficiency (of phosphorous, for example [176]). Constructed wetlands in urban areas are aquatic habitats that can improve biodiversity and possibly even compensate for the loss of the original ecosystems that were present before urbanization. Currently, no generally valid method for evaluating the ecological effects of human-made aquatic habitats in urban areas on biodiversity exists. However, initial approaches have been developed [177-179]. When evaluating the effects of constructed wetlands on biodiversity, it needs to be taken into account that they are part of a larger system of urban green infrastructure [180]. Finally, the attractiveness of applying constructed wetlands in urban areas can be increased by harvesting and re-using their plant biomass-ideally at an adjacent location. Hultberg et al. [181] for example, showed that a wetland's reed biomass can be used as substrate for the production of oyster mushrooms (Pleurotus ostreatus), with $1 \mathrm{~kg}$ of reed (dry weight) resulting in $1.4 \mathrm{~kg}$ of mushrooms (fresh weight). As a result, harvesting a wetland's plant biomass not only reduced the risk of its eutrophication but also served as the basis for food production.

\subsection{Combining Green Roofs and Constructed Wetlands in Urban Settings}

The advantages of green roofs and constructed wetlands can be combined in the cramped environment of growing cities by planting wetland plants (Figure 9) on the roofs of buildings [16,182].

This approach is a suitable tool for the decentralized management of rainwater and greywater for future use. At the same time, the two eco-technologies can complement existing urban green infrastructure. They should, however, not be used as a substitute for other green spaces. Instead, by complementing existing green spaces, green roofs and constructed wetlands could minimize the negative effects of isolation and fragmentation on biodiversity, for example. The targeted combination of constructed wetlands and green roofs and the increased use of these eco-technologies in urban areas can result in more comprehensive positive impacts on biodiversity in the future relative to the sporadic, isolated use of these technologies. 


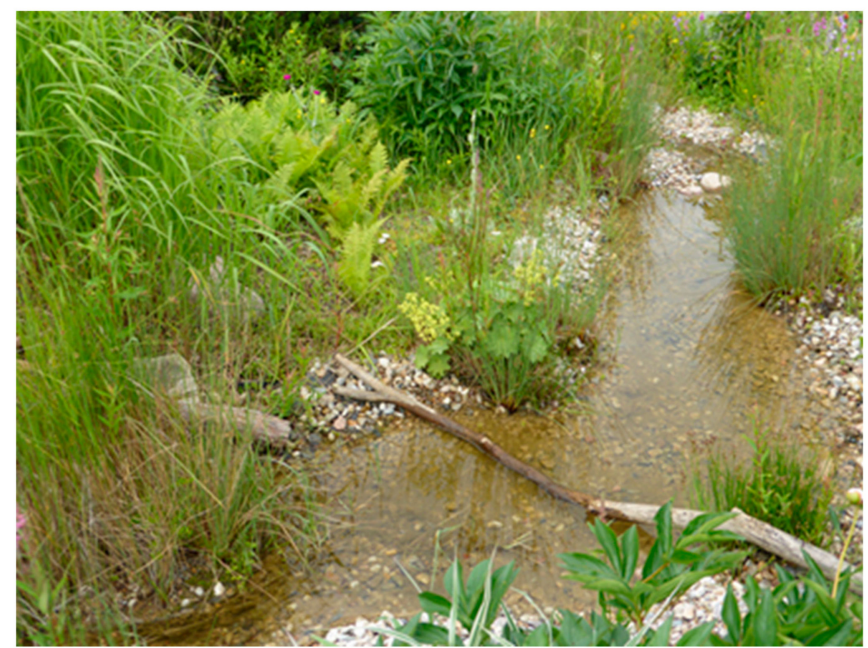

Figure 9. This wetland, which has been integrated into a green roof, supports the presence of plants and animals usually absent from green roofs. (Photo: A. Z.).

Supplementary Materials: The following are available online at http://www.mdpi.com/2071-1050/11/20/5846/s1, Table S1a: Overview of all 77 articles that were included in the review of the effects of green roofs on biodiversity in urban areas; Table S1b: Overview of articles that were excluded from the review on effects of green roofs on biodiversity in urban areas due to one or several of the following reasons: no focus on green roofs, no focus on effects of green roofs on biodiversity, conceptual article, no access to the article (online or through a direct request to the author). The following are available online at http://www.mdpi.com/2071-1050/11/20/5846/s2, Table S2a: Overview of all 65 articles that were included in the review of the effects of constructed wetlands on biodiversity in urban areas; Table S2b: Overview of articles that were excluded from the review on effects of constructed wetlands on biodiversity in urban areas due to one or several of the following reasons: no focus on constructed wetlands, no focus on effects of constructed wetlands on biodiversity, conceptual article, no access to the article (online or through a direct request to the author), focus on microorganisms.

Author Contributions: Conceptualization, S.K., S.S., and A.Z.; methodology, S.K and A.Z.; formal analysis, S.K. and A.Z.; investigation, S.K. (abstract scanning, analyzing green roof articles) and A.Z. (analyzing constructed wetlands articles); resources, S.K. and A.Z.; data curation, S.K. and A.Z.; supervision, S.K. and A.Z.; writing-original draft preparation, S.K., S.S., and A.Z.; writing-review and editing, S.K., S.S., and A.Z.; visualization, S.K., S.S., and A.Z.

Funding: This research received no external funding.

Acknowledgments: We thank all authors who provided their articles for this review in cases where these articles were not accessible for us and had to be requested.

Conflicts of Interest: The authors declare no conflict of interest. The funders had no role in the design of the study; in the collection, analyses, or interpretation of data; in the writing of the manuscript, or in the decision to publish the results.

\section{References}

1. United Nations Department of Economic and Social Affairs Population Division. World Urbanization Prospects: The 2018 Revision, Online ed.; United Nations Department of Economic and Social Affairs Population Division: New York, NY, USA, 2018.

2. Barton, H. Land use planning and health and well-being. Land Use Policy 2009, 26, S115-S123. [CrossRef]

3. Kowarik, I. Novel urban ecosystems, biodiversity, and conservation. Environ. Pollut. 2011, 159, $1974-1983$. [CrossRef] [PubMed]

4. Natural Capital Germany-TEEB DE. Ecosystem Services in the City-Protecting Health and Enhancing Quality of Life. Summary for Deci-Sion-Makers; Technical University of Berlin, Helmholtz Centre for Environmental Research-UFZ: Berlin, Germany; Leipzig, Germany, 2017.

5. European Union. The EU Biodiversity Strategy to 2020; Publications Office of the European Union: Luxembourg, 2011.

6. European Commission Green Infrastructure (GI)_Enhancing Europe's Natural Capital. Available online: https://eur-lex.europa.eu/legal-content/EN/TXT/?uri=CELEX:52013DC0249 (accessed on 20 May 2019). 
7. TEEB. The Economics of Ecosystems and Biodiversity: Mainstreaming the Economics of Nature: A Synthesis of the Approach, Conclusions and Recommendations of TEEB. 2010. Available online: http://www.teebweb.org/publication/mainstreaming-the-economics-of-nature-a-synthesis-of-theapproach-conclusions-and-recommendations-of-teeb/ (accessed on 18 October 2019).

8. Die Bundesregierung. Perspektiven für Deutschland. Unsere Strategie für Eine Nachhaltige Entwicklung; Presse-Und Informationsamt der Bundesregierung: Berlin, Germany, 2002.

9. Böhm, J.; Böhme, C.; Bunzel, A.; Landua, D.; Kühnau, C.; Reinke, M. Urbanes Grün in der Doppelten Innenentwicklung; Bundesamt für Naturschutz: Bonn, Germany, 2016; Volume 444.

10. Fischer, L.K.; Honold, J.; Cvejić, R.; Delshammar, T.; Hilbert, S.; Lafortezza, R.; Nastran, M.; Nielsen, A.B.; Pintar, M.; van der Jagt, A.P.N.; et al. Beyond green: Broad support for biodiversity in multicultural European cities. Glob. Environ. Chang. 2018, 49, 35-45. [CrossRef]

11. BMUB - Federal Ministry for the Environment, Nature Conservation, B. and N.S.; BfN-Federal Agency for Nature Conservation. 2015 Nature Awareness Study. Population Survey on Nature and Biological Diversity; BMUB and BfN: Berlin, Germany, 2016.

12. Haaland, C.; van den Bosch, C.K. Challenges and strategies for urban green-space planning in cities undergoing densification: A review. Urban For. Urban Green. 2015, 14, 760-771. [CrossRef]

13. Climate Service Center. Machbarkeitsstudie Starkregenrisiko 2050: Abschlussbericht Kooperationsprojekt des Gesamt-Verbandes der Deutschen Versicherungswirtschaft e. V. (GDV) und des Climate Service Centers (CSC); Climate Service Center: Hamburg, Germany, 2012.

14. Kotowski, A.; Kazmierczak, B.; Nowakowska, M. Analysis of Rainwater Sewerage Systems Overloads on Rakowiec Estate in Wroclaw Caused by Cli-mate Changes. Rocznik Ochrona Srodowiska 2014, 16, 608-626.

15. Teklehaimanot, G.Z.; Kamika, I.; Coetzee, M.A.A.; Momba, M.N.B. Population Growth and Its Impact on the Design Capacity and Performance of the Wastewater Treatment Plants in Sedibeng and Soshanguve, South Africa. Environ. Manag. 2015, 56, 984-997. [CrossRef]

16. Zehnsdorf, A.; Blumberg, M.; Müller, R.A. Helophyte mats (wetland roofs) with high evapotranspiration rates as a tool for decentralised rain-water management-process stability improved by simultaneous greywater treatment. Water Sci. Technol. Water Supply 2019, in press. [CrossRef]

17. Nivala, J.; Zehnsdorf, A.; van Afferden, M.; Müller, R.A. Green infrastructure for increased resource efficiency in urban water management. In Urban transformations-Sustainable Urban Development through Resource Efficiency, Quality of Life and Resilience; Kabisch, S., Koch, F., Gawel, E., Haase, A., Knapp, S., Krellenberg, K., Nivala, J., Zehnsdorf, A., Eds.; Springer International Publishing: Cham, Switzerland, 2018; pp. 133-143.

18. Sailor, D.; Elley, T.B.; Gibson, M. Exploring the building energy impacts of green roof design decisions-A modeling study of buildings in four distinct climates. J. Build. Phys. 2011, 35, 372-391. [CrossRef]

19. Foustalierakia, M.; Assimakopoulosa, M.N.; Santamourisa, M.; Pangalouca, H. Energy performance of a medium scale green roof system installed on a commercial building using numerical and experimental data recorded during the cold period of the year. Energy Build. 2017, 135, 33-38. [CrossRef]

20. Baik, J.-J.; Kwak, K.-H.; Park, S.-B.; Ryu, Y.-H. Effects of building roof greening on air quality in street canyons. Atmos. Environ. 2012, 61, 48-55. [CrossRef]

21. Carter, T.; Jackson, C.R. Vegetated roofs for stormwater management at multiple spatial scales. Landsc. Urban Plan. 2007, 80, 84-94. [CrossRef]

22. Berndtsson, J.C.; Bengtsson, L.; Jinno, K. Runoff water quality from intensive and extensive vegetated roofs. Ecol. Eng. 2009, 35, 369-380. [CrossRef]

23. Williams, N.S.G.; Lundholm, J.; Scott Macivor, J. Do green roofs help urban biodiversity conservation? J. Appl. Ecol. 2014, 51, 1643-1649. [CrossRef]

24. Rosenzweig, M.L. Green roofs: New ecosystems to defend species diversity. Isr. J. Ecol. Evol. 2016, 62, 7-14. [CrossRef]

25. Vymazal, J. Constructed wetlands for wastewater treatment: Five decades of experience. Environ. Sci. Technol. 2011, 45, 61-69. [CrossRef] [PubMed]

26. Da Silva, J.B.; de Oliveira, P.J.A.; Árpád Boncz, M.; Loureiro Paulo, P. A modified constructed wetland system for greywater treatmen. Desalin. Water Treat. 2017, 91, 31-39. [CrossRef]

27. Abtew, W. Evapotranspiration measurements and modeling for three wetland systems in South Florida. J. Am. Water Resour. Assoc. 1996, 32, 465-473. [CrossRef] 
28. Otterpohl, R.; Braun, U.; Oldenburg, M. Innovative technologies for decentralised water-, wastewater and biowaste management in urban and peri-urban areas. Water Sci. Technol. 2004, 48, 23-32. [CrossRef]

29. Steele, M.K.; Heffernan, J.B.; Bettez, N.; Cavender-Bares, J.; Groffman, P.M.; Grove, J.M.; Hall, S.; Hobbie, S.E.; Larson, K.; Morse, J.L.; et al. Convergent Surface Water Distributions in U.S. Cities. Ecosystems 2014, 17, 685-697. [CrossRef]

30. Mao, D.; Wang, Z.; Wu, J.; Wu, B.; Zeng, Y.; Song, K.; Yi, K.; Luo, L. China's wetlands loss to urban expansion. L. Degrad. Dev. 2018, 29, 2644-2657. [CrossRef]

31. Knapp, S.; Kühn, I.; Stolle, J.; Klotz, S. Changes in the functional composition of a Central European urban flora over three centuries. Perspect. Plant Ecol. Evol. Syst. 2010, 12, 235-244. [CrossRef]

32. Pickering, C.; Byrne, J. The benefits of publishing systematic quantitative literature reviews for PhD candidates and other early-career researchers. High. Educ. Res. Dev. 2014, 33, 534-548. [CrossRef]

33. Schweizerischer Ingenieur-und Architektenverein. Begrünung von Dächern; Schweizerischer Ingenieur-und Architektenverein: Zürich, Switzerland, 2013.

34. Moher, D.; Liberati, A.; Tetzlaff, J.; Altman, D.G. PRISMA 2009 Flow Diagram. The PRISMA statement. PLoS Med. 2009, 6, e1000097.

35. Aronson, M.F.J.; La Sorte, F.A.; Nilon, C.H.; Katti, M.; Goddard, M.A.; Lepczyk, C.A.; Warren, P.S.; Williams, N.S.G.; Cilliers, S.; Clarkson, B.; et al. A global analysis of the impacts of urbanization on bird and plant diversity reveals key anthropogenic drivers. Proc. R. Soc. B Biol. Sci. USA 2014, 281, 20133330. [CrossRef] [PubMed]

36. Christoffel, R.A.; Lepczyk, C.A. Representation of herpetofauna in wildlife research journals. J. Wildl. Manag. 2012, 76, 661-669. [CrossRef]

37. Titley, M.A.; Snaddon, J.L.; Turner, E.C. Scientific research on animal biodiversity is systematically biased towards vertebrates and temperate regions. PLoS ONE 2017, 12, e0189577. [CrossRef]

38. Donaldson, M.R.; Burnett, N.J.; Braun, D.C.; Suski, C.D.; Hinch, S.G.; Cooke, S.J.; Kerr, J.T. Taxonomic bias and international biodiversity conservation research. Facets 2016, 1, 105-113. [CrossRef]

39. Rumble, H.; Finch, P.; Gange, A.C. Green roof soil organisms: Anthropogenic assemblages or natural communities? Appl. Soil Ecol. 2018, 126, 11-20. [CrossRef]

40. Vasl, A.; Shalom, H.; Kadas, G.J.; Blaustein, L. Sedum-Annual plant interactions on green roofs: Facilitation, competition and exclusion. Ecol. Eng. 2017, 108, 318-329. [CrossRef]

41. Molineux, C.J.; Gange, A.C.; Connop, S.P.; Newport, D.J. Using recycled aggregates in green roof substrates for plant diversity. Ecol. Eng. 2015, 82, 596-604. [CrossRef]

42. McKinney, M.L.; Sisco, N.D. Systematic Variation in Roof Spontaneous Vegetation: Residential "Low Rise" Versus Commercial “High Rise” Buildings. Urban Nat. 2018, SI, 73-88.

43. Ksiazek-Mikenas, K.; Herrmann, J.; Menke, S.B.; Köhler, M. If You Build It, Will They Come? Plant and Arthropod Diversity on Urban Green Roofs Over Time. Urban Nat. 2018, 1, 52-72.

44. Catalano, C.; Marcenò, C.; Laudicina, V.A.; Guarino, R. Thirty years unmanaged green roofs: Ecological research and design implications. Landsc. Urban Plan. 2016, 149, 11-19. [CrossRef]

45. Klein, P.M.; Coffman, R. Establishment and performance of an experimental green roof under extreme climatic conditions. Sci. Total Environ. 2015, 512, 82-93. [CrossRef]

46. Schrader, S.; Böning, M. Soil formation on green roofs and its contribution to urban biodiversity with emphasis on Collembolans. Pedobiologia (Jena) 2006, 50, 347-356. [CrossRef]

47. McGuire, K.L.; Payne, S.G.; Palmer, M.I.; Gillikin, C.M.; Keefe, D.; Kim, S.J.; Gedallovich, S.M.; Discenza, J.; Rangamannar, R.; Koshner, J.A.; et al. Digging the New York City Skyline: Soil Fungal Communities in Green Roofs and City Parks. PLoS ONE 2013, 8, e58020. [CrossRef]

48. Eakin, C.J.; Campa, H.; Linden, D.W.; Roloff, G.J.; Bradley Rowe, D.; Westphal, J. Avian response to green roofs in urban landscapes in the Midwestern USA. Wildl. Soc. Bull. 2015, 39, 574-582. [CrossRef]

49. Tonietto, R.; Fant, J.; Ascher, J.; Ellis, K.; Larkin, D. A comparison of bee communities of Chicago green roofs, parks and prairies. Landsc. Urban Plan. 2011, 103, 102-108. [CrossRef]

50. Madre, F.; Vergnes, A.; Machon, N.; Clergeau, P. A comparison of 3 types of green roof as habitats for arthropods. Ecol. Eng. 2013, 57, 109-117. [CrossRef]

51. Blank, L.; Vasl, A.; Schindler, B.Y.; Kadas, G.J.; Blaustein, L. Horizontal and vertical island biogeography of arthropods on green roofs: A review. Urban Ecosyst. 2017, 20, 911-917. [CrossRef] 
52. Thuring, C.; Grant, G. The biodiversity of temperate extensive green roofs-A review of research and practice. Isr. J. Ecol. Evol. 2016, 62, 44-57. [CrossRef]

53. Joimel, S.; Grard, B.; Auclerc, A.; Hedde, M.; Le Doaré, N.; Salmon, S.; Chenu, C. Are Collembola "flying" onto green roofs? Ecol. Eng. 2018, 111, 117-124. [CrossRef]

54. Nagase, A.; Yamada, Y.; Aoki, T.; Nomura, M. Developing Biodiverse Green Roofs for Japan: Arthropod and Colonizer Plant Diversity on Harappa and Biotope Roofs. Urban Nat. 2018, 1, 16-38.

55. Deng, H.; Jim, C.Y. Spontaneous plant colonization and bird visits of tropical extensive green roof. Urban Ecosyst. 2017, 20, 337-352. [CrossRef]

56. Kandas, G. Rare Invertebrates Colonizing Green Roofs in London. Urban Habitat 2006, 4, 66-86.

57. Partridge, D.R.; Clark, J.A. Urban green roofs provide habitat for migrating and breeding birds and their arthropod prey. PLoS ONE 2018, 13, e0202298. [CrossRef] [PubMed]

58. Parkins, K.L.; Clark, J.A. Green roofs provide habitat for urban bats. Glob. Ecol. Conserv. 2015, 4, 349-357. [CrossRef]

59. Washburn, B.E.; Swearingin, R.M.; Pullins, C.K.; Rice, M.E. Composition and Diversity of Avian Communities Using a New Urban Habitat: Green Roofs. Environ. Manag. 2016, 57, 1230-1239. [CrossRef]

60. Pearce, H.; Walters, C.L. Do Green Roofs Provide Habitat for Bats in Urban Areas? Acta Chiropterol. 2012, 14, 469-478. [CrossRef]

61. Heim, A.; Lundholm, J. The effects of substrate depth heterogeneity on plant species coexistence on an extensive green roof. Ecol. Eng. 2014, 68, 184-188. [CrossRef]

62. Van Mechelen, C.; Van Meerbeek, K.; Dutoit, T.; Hermy, M. Functional diversity as a framework for novel ecosystem design: The example of extensive green roofs. Landsc. Urban Plan. 2015, 136, 165-173. [CrossRef]

63. Walker, E.A.; Lundholm, J.T. Designed habitat heterogeneity on green roofs increases seedling survival but not plant species diversity. J. Appl. Ecol. 2018, 55, 694-704. [CrossRef]

64. Dunnett, N.; Nagase, A.; Hallam, A. The dynamics of planted and colonising species on a green roof over six growing seasons 2001-2006: Influence of substrate depth. Urban Ecosyst. 2008, 11, 373-384. [CrossRef]

65. Brown, C.; Lundholm, J. Microclimate and substrate depth influence green roof plant community dynamics. Landsc. Urban Plan. 2015, 143, 134-142. [CrossRef]

66. Braaker, S.; Obrist, M.K.; Ghazoul, J.; Moretti, M. Habitat connectivity and local conditions shape taxonomic and functional diversity of arthropods on green roofs. J. Anim. Ecol. 2017, 86, 521-531. [CrossRef]

67. Kyrö, K.; Brenneisen, S.; Kotze, D.J.; Szallies, A.; Gerner, M.; Lehvävirta, S. Local habitat characteristics have a stronger effect than the surrounding urban landscape on beetle communities on green roofs. Urban For. Urban Green. 2018, 29, 122-130. [CrossRef]

68. Molineux, C.J.; Gange, A.C.; Newport, D.J. Using soil microbial inoculations to enhance substrate performance on extensive green roofs. Sci. Total Environ. 2017, 580, 846-856. [CrossRef]

69. Nagase, A.; Dunnett, N.; Choi, M.S. Investigation of weed phenology in an establishing semi-extensive green roof. Ecol. Eng. 2013, 58, 156-164. [CrossRef]

70. MacIvor, J.S.; Margolis, L.; Puncher, C.L.; Carver Matthews, B.J. Decoupling factors affecting plant diversity and cover on extensive green roofs. J. Environ. Manag. 2013, 130, 297-305. [CrossRef]

71. Aloisio, J.M.; Palmer, M.I.; Giampieri, M.A.; Tuininga, A.R.; Lewis, J.D. Spatially dependent biotic and abiotic factors drive survivorship and physical structure of green roof vegetation. Ecol. Appl. 2017, 27, 297-308. [CrossRef]

72. Nash, C.; Clough, J.; Gedge, D.; Lindsay, R.; Newport, D.; Ciupala, M.A.; Connop, S. Initial insights on the biodiversity potential of biosolar roofs: A London Olympic Park green roof case study. Isr. J. Ecol. Evol. 2016, 62, 74-87. [CrossRef]

73. Schindler, B.Y.; Blank, L.; Levy, S.; Kadas, G.; Pearlmutter, D.; Blaustein, L. Integration of photovoltaic panels and green roofs: Review and predictions of effects on electricity production and plant communities. Isr. J. Ecol. Evol. 2016, 62, 68-73. [CrossRef]

74. Grant, G. Extensive green roofs in London. Urban Habitats 2006, 4, 51-65.

75. Benvenuti, S. Wildflower green roofs for urban landscaping, ecological sustainability and biodiversity. Landsc. Urban Plan. 2014, 124, 151-161. [CrossRef]

76. Rumble, H.; Gange, A.C. Soil microarthropod community dynamics in extensive green roofs. Ecol. Eng. 2013, 57, 197-204. [CrossRef] 
77. Braaker, S.; Ghazoul, J.; Obrist, M.K.; Moretti, M. Habitat connectivity shapes urban arthropod communities: The key role of green roofs. Ecology 2014, 95, 1010-1021. [CrossRef]

78. Molineux, C.J.; Gange, A.C.; Connop, S.P.; Newport, D.J. Are microbial communities in green roof substrates comparable to those in post-industrial sites?-A preliminary study. Urban Ecosyst. 2015, 18, 1245-1260. [CrossRef]

79. MacIvor, J.S.; Lundholm, J. Insect species composition and diversity on intensive green roofs and adjacent level-ground habitats. Urban Ecosyst. 2011, 14, 225-241. [CrossRef]

80. Ksiazek, K.; Fant, J.; Skogen, K. An assessment of pollen limitation on Chicago green roofs. Landsc. Urban Plan. 2012, 107, 401-408. [CrossRef]

81. Schmauck, S. Dach-und Fassadenbegrünung - neue Lebensräume im Siedlungsbereich. Fakten, Argumente und Empfehlungen. BfN-Skripten 2019, 538, 1-64.

82. Baumann, N. Ground-Nesting Birds on Green Roofs in Switzerland: Preliminary Observations. Urban Habitats 2006, 4, 37-50.

83. Baumann, N. Ecological compensation on the roof: Ground-nesting birds and vegetation. In World Green Roof Congress; World Green Roof Congress Proceedings: London, UK, 2010.

84. Cook-Patton, S.C.; Bauerle, T.L. Potential benefits of plant diversity on vegetated roofs: A literature review. J. Environ. Manag. 2012, 106, 85-92. [CrossRef] [PubMed]

85. Lundholm, J.; Heim, A.; Tran, S.; Smith, T. Leaf and Life History Traits Predict Plant Growth in a Green Roof Ecosystem. PLoS ONE 2014, 9, e101395.s. [CrossRef] [PubMed]

86. Getter, K.L.; Rowe, D.B. Media depth influences Sedum green roof establishment. Urban Ecosyst. 2008, 11, 361-372. [CrossRef]

87. Yalcinalp, E.; Ozveren, S.; Meral, A.; Pulatkan, M.; Akbulut, S. Habitat effect on urban roof vegetation. Sustainability 2017, 9, 1985. [CrossRef]

88. Köhler, M.; Poll, P.H. Long-term performance of selected old Berlin greenroofs in comparison to younger extensive greenroofs in Berlin. Ecol. Eng. 2010, 36, 722-729. [CrossRef]

89. Van Mechelen, C.; Dutoit, T.; Hermy, M. Vegetation development on different extensive green roof types in a Mediterranean and temperate maritime climate. Ecol. Eng. 2015, 82, 571-582. [CrossRef]

90. Bates, A.J.; Sadler, J.P.; Greswell, R.B.; Mackay, R. Effects of varying organic matter content on the development of green roof vegetation: A six year experiment. Ecol. Eng. 2015, 82, 301-310. [CrossRef]

91. Bates, A.J.; Sadler, J.P.; Greswell, R.B.; Mackay, R. Effects of recycled aggregate growth substrate on green roof vegetation development: A six year experiment. Landsc. Urban Plan. 2015, 135, 22-31. [CrossRef]

92. Bornkamm, R. Vegetation und vegetations-entwicklung auf Kiesdächern. Vegetatio 1961, 10, 1-24. [CrossRef]

93. Bates, A.J.; Sadler, J.P.; Mackay, R. Vegetation development over four years on two green roofs in the UK. Urban For. Urban Green. 2013, 12, 98-108. [CrossRef]

94. Lundholm, J.; Tran, S.; Gebert, L. Plant functional traits predict green roof ecosystem services. Environ. Sci. Technol. 2015, 49, 2366-2374. [CrossRef] [PubMed]

95. Villéger, S.; Mason, N.W.H.; Mouillot, D. New multidimensional functional diversity indices for a multifaceted framework in functional ecology. Ecology 2008, 89, 2290-2301. [CrossRef] [PubMed]

96. Garnier, E.; Cortez, J.; Billès, G.; Navas, M.L.; Roumet, C.; Debussche, M.; Laurent, G.; Blanchard, A.; Aubry, D.; Bellmann, A.; et al. Plant functional markers capture ecosystem properties during secondary succession. Ecology 2004, 85, 2630-2637. [CrossRef]

97. Čeplová, N.; Lososová, Z.; Zelený, D.; Chytrý, M.; Danihelka, J.; Fajmon, K.; Láníková, D.; Preislerová, Z.; Řehořek, V.; Tíchý, L. Phylogenetic diversity of central-European urban plant communities: Effects of alien species and habitat types. Preslia 2015, 87, 1-16.

98. Holt, R.D. Green roofs may cast shadows. Isr. J. Ecol. Evol. 2016, 62, 15-22. [CrossRef]

99. Ricotta, C.; Moretti, M. CWM and Rao's quadratic diversity: A unified framework for functional ecology. Oecologia 2011, 167, 181-188. [CrossRef]

100. Madre, F.; Vergnes, A.; Machon, N.; Clergeau, P. Green roofs as habitats for wild plant species in urban landscapes: First insights from a large-scale sampling. Landsc. Urban Plan. 2014, 122, 100-107. [CrossRef]

101. Kinlock, N.L.; Schindler, B.Y.; Gurevitch, J. Biological invasions in the context of green roofs. Isr. J. Ecol. Evol. 2016, 62, 32-43. [CrossRef] 
102. Oberndorfer, E.; Lundholm, J.; Bass, B.; Coffman, R.R.; Doshi, H.; Dunnett, N.; Gaffin, S.; Köhler, M.; Liu, K.K.Y.; Rowe, B. Green Roofs as Urban Ecosystems: Ecological Structures, Functions, and Services. Bioscience 2007, 57, 823-833. [CrossRef]

103. Kratschmer, S.; Kriechbaum, M.; Pachinger, B. Buzzing on top: Linking wild bee diversity, abundance and traits with green roof qualities. Urban Ecosyst. 2018, 21, 429-446. [CrossRef]

104. MacIvor, J.S.; Ruttan, A.; Salehi, B. Exotics on exotics: Pollen analysis of urban bees visiting Sedum on a green roof. Urban Ecosyst. 2015, 18, 419-430. [CrossRef]

105. Pétremand, G.; Chittaro, Y.; Braaker, S.; Brenneisen, S.; Gerner, M.; Obrist, M.K.; Rochefort, S.; Szallies, A.; Moretti, M. Ground beetle (Coleoptera: Carabidae) communities on green roofs in Switzerland: Synthesis and perspectives. Urban Ecosyst. 2018, 21, 119-132. [CrossRef]

106. Starry, O.; Gonsalves, S.; Ksiazek-Mikenas, K.; MacIvor, J.S.; Gardner, M.; Szallies, A.; Brenneisen, S. A Global Comparison of Beetle Community Composition on Green Roofs and the Potential for Homogenization. Urban Nat. 2018, 1, 1-15.

107. Kohler, M. Long-term vegetation research on two extensive green roofs in Berlin. Urban Habitats 2006, 4 , 3-26.

108. Cheng, X.Y.; Chen, W.Y.; Gu, B.H.; Liu, X.C.; Chen, F.; Chen, Z.H.; Zhou, X.Y.; Li, Y.X.; Huang, H.; Chen, Y.J. Morphology, ecology, and contaminant removal efficiency of eight wetland plants with differing root systems. Hydrobiologia 2009, 623, 77-85. [CrossRef]

109. Jackson, E.F.; Jackson, C.R. Viruses in wetland ecosystems. Freshw. Biol. 2008, 53, 1214-1227. [CrossRef]

110. Oyuela Leguizamo, M.A.; Fernández Gómez, W.D.; Sarmiento, M.C.G. Native herbaceous plant species with potential use in phytoremediation of heavy metals, spotlight on wetlands-A review. Chemosphere 2017, 168, 1230-1247. [CrossRef]

111. Kuczynski, E.C.; Paszkowski, C.A.; Gingras, B.A. Horned grebe habitat use of constructed wetlands in Alberta, Canada. J. Wildl. Manag. 2012, 76, 1694-1702. [CrossRef]

112. Denton, R.D.; Richter, S.C. Amphibian communities in natural and constructed ridge top wetlands with implications for wetland construction. J. Wildl. Manag. 2013, 77, 886-896. [CrossRef]

113. Hartwig, T.S.; Kiviat, E. Microhabitat Association of Blanding's Turtles in Natural and Constructed Wetlands in Southeastern New York. J. Wildl. Manag. 2007, 71, 576-582. [CrossRef]

114. Balcombe, C.K.; Anderson, J.T.; Fortney, R.H.; Rentch, J.S.; Grafton, W.N.; Kordek, W.S. A comparison of plant communities in mitigation and reference wetlands in the mid-appalachians. Wetlands 2006, 25, 130-142. [CrossRef]

115. Barbosa, B.; Costa, J.; Fernando, A.L.; Papazoglou, E.G. Wastewater reuse for fiber crops cultivation as a strategy to mitigate desertification. Ind. Crops Prod. 2015, 68, 17-23. [CrossRef]

116. Benami, M.; Gross, A.; Herzberg, M.; Orlofsky, E.; Vonshak, A.; Gillor, O. Assessment of pathogenic bacteria in treated graywater and irrigated soils. Sci. Total Environ. 2013, 458-460, 298-302. [CrossRef] [PubMed]

117. Sindilariu, P.-D.; Reiter, R.; Wedekind, H. Impact of trout aquaculture on water quality and farm effluent treatment options. Aquat. Living Resour. 2009, 22, 93-103. [CrossRef]

118. Yoon, C.G. Wise use of paddy rice fields to partially compensate for the loss of natural wetlands. Paddy Water Environ. 2009, 7, 357-366. [CrossRef]

119. Lacki, M.J.; Hummer, J.W.; Webster, H.J. Effect of Reclamation Technique on Mammal Communitites Inhabiting Wetlands on Mined Lands in East-Central Ohio. Ohio J. Sci. 1991, 92, 154-158.

120. De Martis, G.; Mulas, B.; Malavasi, V.; Marignani, M. Can Artificial Ecosystems Enhance Local Biodiversity? The Case of a Constructed Wetland in a Mediterranean Urban Context. Environ. Manag. 2016, 57, 1088-1097. [CrossRef]

121. Hsu, C.B.; Hsieh, H.L.; Yang, L.; Wu, S.H.; Chang, J.S.; Hsiao, S.C.; Su, H.C.; Yeh, C.H.; Ho, Y.S.; Lin, H.J. Biodiversity of constructed wetlands for wastewater treatment. Ecol. Eng. 2011, 37, 1533-1545. [CrossRef]

122. Van Loon, E.E.; Bos, D.; van Hellenberg Hubar, C.J.; Ydenberg, R.C. A historical perspective on the effects of trapping and controlling the muskrat (Ondatra zibethicus) in the Netherlands. Pest Manag. Sci. 2017, 73, 305-312. [CrossRef]

123. Kadlec, R.H.; Pries, J.; Mustard, H. Muskrats (Ondatra zibethicus) in treatment wetlands. Ecol. Eng. 2007, 29, 143-153. [CrossRef]

124. Greenhorn, J.E.; Sadowski, C.; Holden, J.; Bowman, J. Coastal Wetlands Connected to Lake Ontario Have Reduced Muskrat (Ondatra zibethicus) Abundance. Wetlands 2017, 37, 339-349. [CrossRef] 
125. Orłowski, G. Factors affecting the use of waste-stabilization ponds by birds: A case study of conservation implications of a sewage farm in Europe. Ecol. Eng. 2013, 61, 436-445. [CrossRef]

126. Scarton, F. Long-term trend of the waterbird community breeding in a heavily man-modified coastal lagoon: The case of the important bird area "Lagoon of Venice" . J. Coast. Conserv. 2017, 21, 35-45. [CrossRef]

127. Lin, J.L.; Tu, Y.T.; Chiang, P.C.; Chen, S.H.; Kao, C.M. Using aerated gravel-packed contact bed and constructed wetland system for polluted river water purification: A case study in Taiwan. J. Hydrol. 2015, 525, 400-408. [CrossRef]

128. Strand, J.A.; Weisner, S.E.B. Effects of wetland construction on nitrogen transport and species richness in the agricultural landscape-Experiences from Sweden. Ecol. Eng. 2013, 56, 14-25. [CrossRef]

129. Scheffers, B.R.; Paszkowski, C.A. Amphibian use of urban stormwater wetlands: The role of natural habitat features. Landsc. Urban Plan. 2013, 113, 139-149. [CrossRef]

130. Drayer, A.N.; Richter, S.C. Physical wetland characteristics influence amphibian community composition differently in constructed wetlands and natural wetlands. Ecol. Eng. 2016, 93, 166-174. [CrossRef]

131. Furman, B.L.S.; Scheffers, B.R.; Taylor, M.; Davis, C.; Paszkowski, C.A. Limited genetic structure in a wood frog (Lithobates sylvaticus) population in an urban landscape inhabiting natural and constructed wetlands. Conserv. Genet. 2016, 17, 19-30. [CrossRef]

132. Mulkeen, C.J.; Gibson-Brabazon, S.; Carlin, C.; Williams, C.D.; Healy, M.G.; Mackey, P.; Gormally, M.J. Habitat suitability assessment of constructed wetlands for the smooth newt (Lissotriton vulgaris [Linnaeus, 1758]): A comparison with natural wetlands. Ecol. Eng. 2017, 106, 532-540. [CrossRef]

133. Shulse, C.D.; Semlitsch, R.D.; Trauth, K.M.; Williams, A.D. Influences of design and landscape placement parameters on amphibian abundance in constructed wetlands. Wetlands 2010, 30, 915-928. [CrossRef]

134. Walton, W.E.; Workman, P.D. Effect of marsh design on the abundance of mosquitoes in experimental constructed wetlands in Southern California. J. Am. Mosq. Control Assoc. 1998, 14, 95-107. [PubMed]

135. Walton, W.E. Design and management of free water surface constructed wetlands to minimize mosquito production. Wetl. Ecol. Manag. 2012, 20, 173-195. [CrossRef]

136. Molnár, Á.; Csabai, Z.; Tóthmérész, B. Influence of Flooding and Vegetation Patterns on Aquatic Beetle Diversity in a Constructed Wetland Complex. Wetlands 2009, 29, 1214-1223. [CrossRef]

137. Becerra-Jurado, G.; Foster, G.; Harrington, R.; Kelly-Quinn, M. Integrated constructed wetlands: Hotspots for freshwater coleopteran diversity in the landscape of Ireland. Biol. Environ. 2014, 114B, 271-279. [CrossRef]

138. Steinly, B.A. Primary consumer and detritivore communities (Diptera: Ephydridae) in newly restored and constructed wetlands. Proc. Entomol. Soc. Washingt. USA 2004, 106, 460-471.

139. Becerra Jurado, G.; Johnson, J.; Feeley, H.; Harrington, R.; Kelly-Quinn, M. The potential of integrated constructed wetlands (ICWs) to enhance macroinvertebrate diversity in agricultural landscapes. Wetlands 2010, 30, 393-404. [CrossRef]

140. Becerra-Jurado, G.; Harrington, R.; Kelly-Quinn, M. A review of the potential of surface flow constructed wetlands to enhance macroinvertebrate diversity in agricultural landscapes with particular reference to Integrated Constructed Wetlands (ICWs). Hydrobiologia 2012, 692, 121-130. [CrossRef]

141. Holtmann, L.; Juchem, M.; Brüggeshemke, J.; Möhlmeyer, A.; Fartmann, T. Stormwater ponds promote dragonfly (Odonata) species richness and density in urban areas. Ecol. Eng. 2018, 118, 1-11. [CrossRef]

142. Giordano, R.; Weber, E.; Darby, B.J.; Soto-Adames, F.N.; Murray, R.E.; Drizo, A. Invertebrates Associated With a Horizontal-Flow, Subsurface Constructed Wetland in a Northern Climate. Environ. Entomol. 2014, 43, 283-290. [CrossRef]

143. Ouattara, J.M.P.; Coulibaly, L.; Tiho, S.; Gourène, G. Comparison of macrofauna communities in sediments of the beds of vertical flow constructed wetlands planted with Panicum maximum (Jacq.) treating domestic wastewater. Ecol. Eng. 2009, 35, 1237-1242. [CrossRef]

144. Ouattara, J.M.P.; Coulibaly, L.; Tiho, S.; Ouattara, A.; Gourène, G. Panicum maximum (Jacq.) density effect upon macrofauna structure in sediments of pilot-scale vertical flow constructed wetlands treating domestic wastewater. Ecol. Eng. 2011, 37, 217-223. [CrossRef]

145. Pedescoll, A.; Rodríguez, L.; Sarañana, A.A.; Hijosa-Valsero, M.; Bécares, E. Microfaunal community in horizontal constructed wetlands with different design configurations. Ecol. Eng. 2016, 91, 16-23. [CrossRef]

146. Spieles, D.J.; Horn, J.D. Macroinvertebrate community structure in created wetlands of different successional stage. Aquat. Ecosyst. Heal. Manag. 2009, 12, 320-329. [CrossRef] 
147. Zehnsdorf, A.; Scherber, A.; Schmidt, S.; Ebersbach, A.T.; Bernhard, K.; Jentzsch, D.; Schlenker, U. Waste Water Treatment with Reeds in a Mobile Root Space Treatment Plant. Chem. Ing. Tech. 2018, 90, 333-339. [CrossRef]

148. Barczak, T.; Bennewicz, J.; Kaminski, P. Parasitoids (Hymenoptera: Braconidae, aphidiinae) of the mealy plum aphid Hyalopterus pruni (geoffr.) on common reed (Phragmites australis) in different types of habitat in poland. Arch. Biol. Sci. 2013, 65, 71-79.

149. Basky, Z. Predators and Parasites of Hyalopterus-pruni and Hyalopterus-amygdali populations living on Peach, Plum and Reed. Acta Phytopathol. Acad. Sci. Hung. 1982, 17, 311-316.

150. Mann, G. Rückhalt, Abflussverzögerung, Speicherung. Greenbuild. Mag. 2015, 6/15, 3.

151. Lisecke, H.-J. Das Retentionsvermögen von Dachbegrünungen. Wasserspeicherfähigkeit, Wasserrückhaltung, Abflussverzögerung und Abflussbeiwerte unter besonderer Berücksichtigung von Extensivbegrünungen. Stadt Grün 1998, 47, 46-53.

152. Deutschewitz, K.; Lausch, A.; Kühn, I.; Klotz, S. Native and alien plant species richness in relation to spatial heterogeneity on a regional scale in Germany. Glob. Ecol. Biogeogr. 2003, 12, 299-311. [CrossRef]

153. Vanuytrecht, E.; Van Mechelen, C.; Van Meerbeek, K.; Willems, P.; Hermy, M.; Raes, D. Runoff and vegetation stress of green roofs under different climate change scenarios. Landsc. Urban Plan. 2014, 122, 68-77. [CrossRef]

154. Brenneisen, S. Space for urban wildlife: Designing green roofs as habitats in Switzerland. Urban Habitats 2006, 4, 27-36.

155. Catalano, C.; Laudicina, V.A.; Badalucco, L.; Guarino, R. Some European green roof norms and guidelines through the lens of biodiversity: Do ecoregions and plant traits also matter? Ecol. Eng. 2018, 115, 15-26. [CrossRef]

156. Dunnett, N. Ruderal green roofs. In Green Roof Ecosystems; Sutton, R.K., Ed.; Springer: Cham, Switzerland, 2015; pp. 233-255.

157. Hirschfelder, A.; Zucchi, H. Zur Besiedelung begrünter Gebäudedächer durch Carabiden—Ein Beitrag zur Stadtökologie. Zeitschrift für Ökologie und Naturschutz 1992, 1, 59-66.

158. Buch, C.; Jagel, A. Schmetterlingswiese, Bienenschmaus und Hummelmagnet-Insektenrettung aus der Samentüte? Veröffentlichungen Bochumer Botanischen Vereins 2019, 11, 9-24.

159. Hauck, T.E.; Weisser, W.W. AAD—Animal-aided design; Technische Universität München: München, Germany; Universität Kassel: Kassel, Germany, 2016.

160. Roy, M.C.; Foote, L.; Ciborowski, J.J.H. Vegetation community composition in wetlands created following oil sand mining in Alberta, Canada. J. Environ. Manag. 2016, 172, 18-28. [CrossRef]

161. Crowe, A.U.; Plant, A.L.; Kermode, A.R. Effects of an industrial effluent on plant colonization and on the germination and post-germinative growth of seeds of terrestrial and aquatic plant species. Environ. Pollut. 2002, 117, 179-189. [CrossRef]

162. Liu, J.; Wang, J.; Zhao, C.; Hay, A.G.; Xie, H.; Zhan, J. Triclosan removal in wetlands constructed with different aquatic plants. Appl. Microbiol. Biotechnol. 2016, 100, 1459-1467. [CrossRef]

163. Zhang, C.B.; Wang, J.; Liu, W.L.; Zhu, S.X.; Ge, H.L.; Chang, S.X.; Chang, J.; Ge, Y. Effects of plant diversity on microbial biomass and community metabolic profiles in a full-scale constructed wetland. Ecol. Eng. 2010, 36, 62-68. [CrossRef]

164. Zhang, C.B.; Ke, S.S.; Wang, J.; Ge, Y.; Chang, S.X.; Zhu, S.X.; Chang, J. Responses of microbial activity and community metabolic profiles to plant functional group diversity in a full-scale constructed wetland. Geoderma 2011, 160, 503-508. [CrossRef]

165. Zhang, C.B.; Liu, W.L.; Han, W.J.; Guan, M.; Wang, J.; Liu, S.Y.; Ge, Y.; Chang, J. Responses of Dissimilatory Nitrate Reduction to Ammonium and Denitrification to Plant Presence, Plant Species and Species Richness in Simulated Vertical Flow Constructed Wetlands. Wetlands 2017, 37, 109-122. [CrossRef]

166. Zhu, S.; Huang, X.; Ho, S.H.; Wang, L.; Yang, J. Effect of plant species compositions on performance of lab-scale constructed wetland through investigating photosynthesis and microbial communities. Bioresour. Technol. 2017, 229, 196-203. [CrossRef] [PubMed]

167. Zhang, C.B.; Liu, W.L.; Wang, J.; Chen, T.; Yuan, Q.Q.; Huang, C.C.; Ge, Y.; Chang, S.X.; Chang, J. Plant functional group richness-affected microbial community structure and function in a full-scale constructed wetland. Ecol. Eng. 2011, 37, 1360-1368. [CrossRef]

168. Brister, J.S.; Nelson, A.D. Vegetative ecology of natural and constructed wetlands along the Leon River in Comanche County, Texas. Tex. J. Sci. 2012, 64, 103-128. 
169. Mitsch, W.J.; Zhang, L.; Waletzko, E.; Bernal, B. Validation of the ecosystem services of created wetlands: Two decades of plant succession, nutrient retention, and carbon sequestration in experimental riverine marshes. Ecol. Eng. 2014, 72, 11-24. [CrossRef]

170. White, S.A.; Taylor, M.D.; Damrel, D.Z. Floral Colonization of a Free-Water Surface Constructed Wetland System in Grady County, Georgia. Castanea 2012, 77, 159-171. [CrossRef]

171. Pier, B.M.; Dresser, B.R.; Lee, J.J.; Boylen, C.W.; Nierzwicki-Bauer, S.A. Ecological Analysis Before and After Planting in a Constructed Wetland in the Adirondacks. Wetlands 2015, 35, 611-624. [CrossRef]

172. Kearney, M.A.; Fickbohm, S.; Zhu, W. Loss of plant biodiversity over a seven-year period in two constructed wetlands in central New York. Environ. Manag. 2013, 51, 1067-1076. [CrossRef]

173. Bae, S.-H.; Lee, S.-D. Construction and Management Plan of Constructed Wetland for Promoting Biodiversity. J. People Plants Environ. 2018, 21, 185-202. [CrossRef]

174. Leck, M.A.; Leck, C.F. Vascular plants of a Delaware River tidal freshwater wetland and adjacent terrestrial areas: Seed bank and vegetation comparisons of reference and constructed marshes and annotated species list 1. J. Torrey Bot. Soc. 2005, 132, 323-354. [CrossRef]

175. Du, Y.; Pan, K.; Yu, C.; Luo, B.; Gu, W.; Sun, H.; Min, Y.; Liu, D.; Geng, Y.; Han, W.; et al. Plant diversity decreases net global warming potential integrating multiple functions in microcosms of constructed wetlands. J. Clean. Prod. 2018, 184, 718-726. [CrossRef]

176. Hansson, L.A.; Brönmark, C.; Nilsson, P.A.; Åbjörnsson, K. Conflicting demands on wetland ecosystem services: Nutrient retention, biodiversity or both? Freshw. Biol. 2005, 50, 705-714. [CrossRef]

177. Tixier, G.; Lafont, M.; Grapentine, L.; Rochfort, Q.; Marsalek, J. Ecological risk assessment of urban stormwater ponds: Literature review and proposal of a new conceptual approach providing ecological quality goals and the associated bioassessment tools. Ecol. Indic. 2011, 11, 1497-1506. [CrossRef]

178. Bullock, J.M.; Aronson, J.; Newton, A.C.; Pywell, R.F.; Rey-Benayas, J.M. Restoration of ecosystem services and biodiversity: Conflicts and opportunities. Trends Ecol. Evol. 2011, 26, 541-549. [CrossRef]

179. Clifford, C.C.; Heffernan, J.B. Artificial aquatic ecosystems. Water 2018, 10, 1096. [CrossRef]

180. Zhang, K.; Chui, T.F.M. Linking hydrological and bioecological benefits of green infrastructures across spatial scales-A literature review. Sci. Total Environ. 2019, 646, 1219-1231. [CrossRef]

181. Hultberg, M.; Prade, T.; Bodin, H.; Vidakovic, A.; Asp, H. Adding benefit to wetlands-Valorization of harvested common reed through mushroom production. Sci. Total Environ. 2018, 637-638, 1395-1399. [CrossRef]

182. Zapater-Pereyra, M.; Lavrnić, S.; van Dien, F.; van Bruggen, J.J.A.; Lens, P.N.L. Constructed wetroofs: A novel approach for the treatment and reuse of domestic wastewater. Ecol. Eng. 2016, 94, 545-554. [CrossRef] 